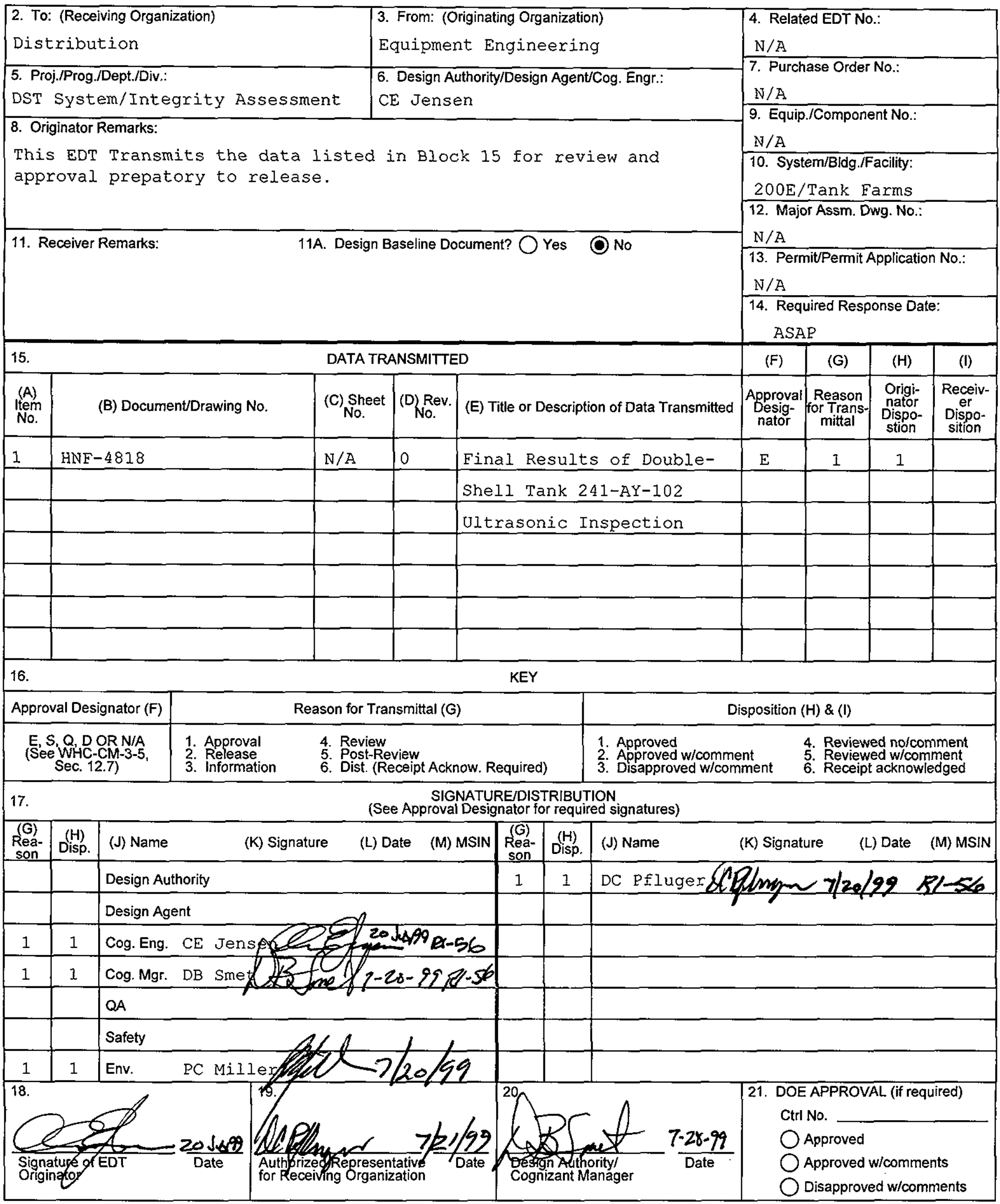




\title{
Final Results of Double-Shell Tank 241-AY-102 Ultrasonic Inspection
}

\author{
C. E. Jensen \\ Lockheed Martin Hanford Corporation, Richland, WA 99352 \\ U.S. Department of Energy Contract DE-AC06-87RL10930
}

EDT/ECN: EDT 623398

Org Code: 74700

B\&R Code: EW3130000
UC: 2000

Charge Code: $106701 / \mathrm{CA} 40$

Total Pages: 59

Key Words: ultrasonic, tank integrity, examination, 241-AY-102, 102-AY, inspection, wall thinning, UT testing, tank wall, UT, integrity assessment, ultrasonic inspection

Abstract: This document presents the results and documentation of the nondestructive ultrasonic examination of tank 241-AY-102. A tank inspection supplier was retained to provide and use an ultrasonic examination system (equipment, procedures, and inspectors) to scan a limited area of double-shell tank 241-AY-102 primary tank wall and welds. The inspection found some indication of insignificant general and local wall thinning with no cracks detected.

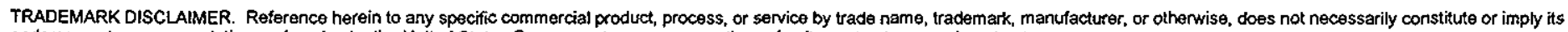
endorsement, recommendation, $\propto$ favoring by the United States Government or any agency thereof or its contractors or subcontractors.

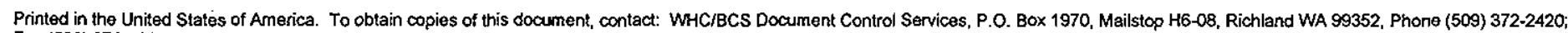
Fax (509) 376-4989.
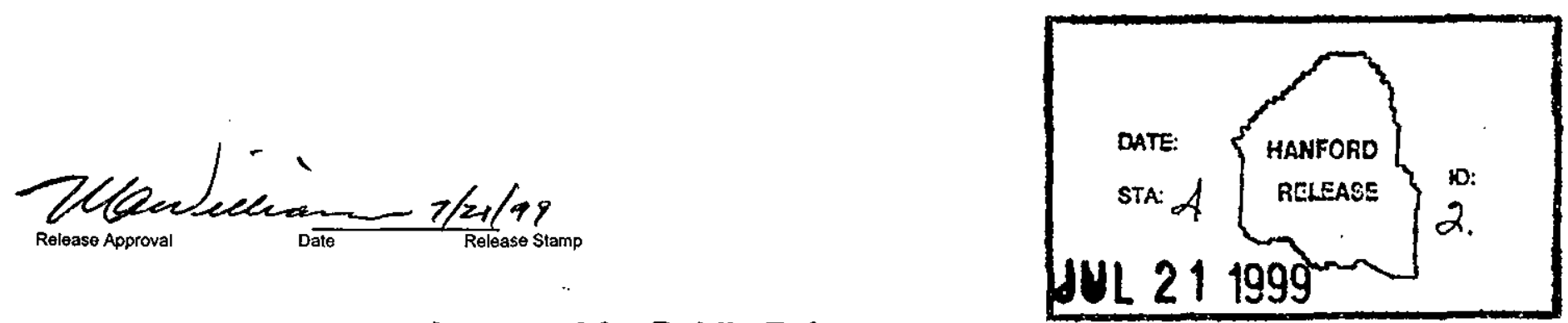


\section{FINAL RESULTS OF DOUBLE-SHELL TANK 241-AY-102 ULTRASONIC INSPECTION}

Prepared By: $\frac{\text { Kadent w. thech Date } 7 / 19 / 99}{\text { R. W. Lysher, COGEMA Engineering Corporation }}$

Reviewed By: $\frac{\text { pAfundal Dende }}{\text { T. S. Hundal, Washington State Registered Professional Engineer }}$ Date $/ 99$ COGEMA Engineering Corporation

Approved By:

$\mathrm{K}$. V. Scott, Manager Date $7 / 19 / 99$ COGEMA Engineering Corporation 
Final Results of Double-Shell Tank 241-AY-102

Ultrasonic Inspection

July 13, 1999

Prepared by

R. W. Lysher

COGEMA Engineering Corporation

for

Lockheed Martin Hanford Corporation

Richland, Washington 
Final Results of Double-Shell Tank 241-AY-102

Ultrasonic Inspection

\section{Table of Contents}

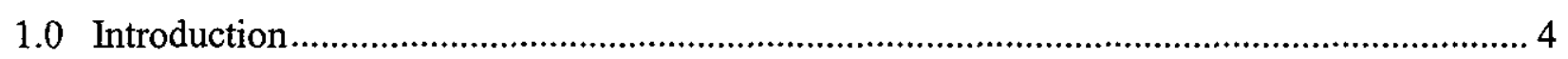

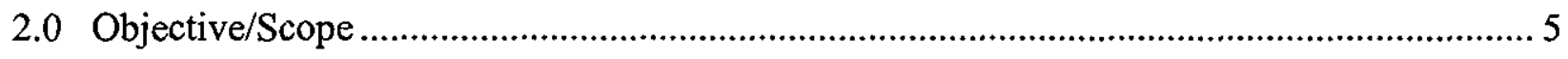

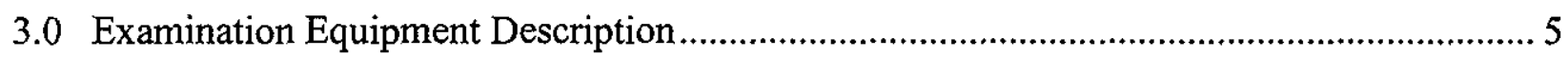

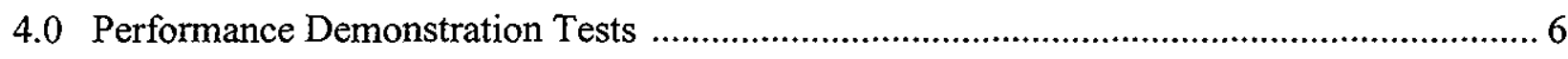

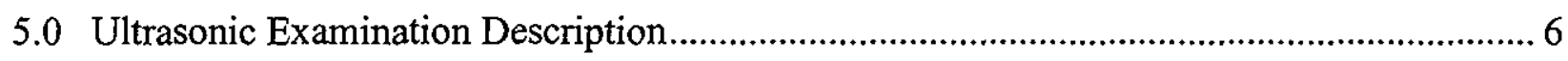

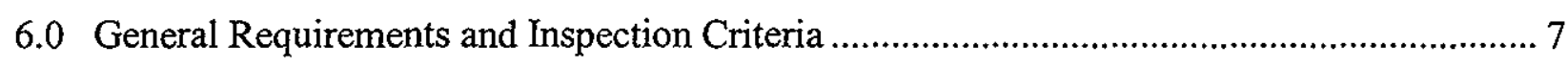

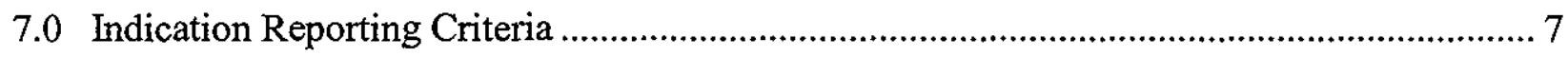

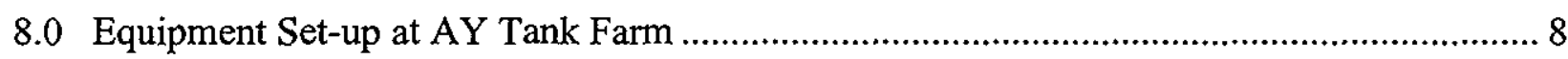

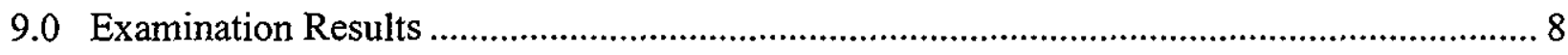

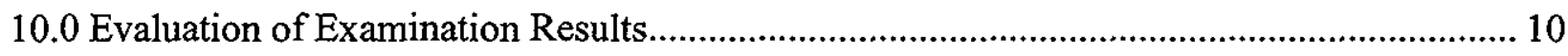

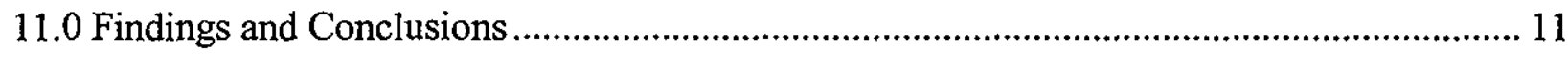

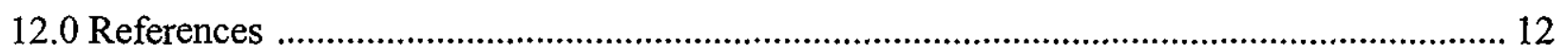

Figure 1 Comparison of As-Measured and ASTM-Specified Plate Thickness with Waste

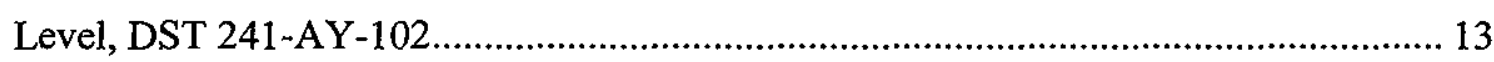

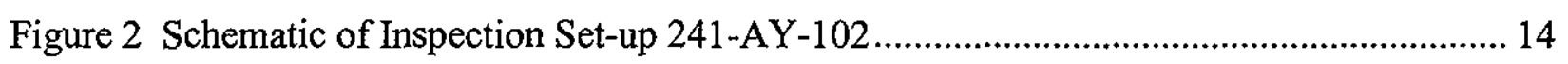

Attachment 1 Ultrasonic Examination of Double-Shell Tank 241-AY-102

Attachment 2 241-AY-102 Double-Shell Tank Ultrasonic Examination Data Reports With Data Sheets 


\section{Double-Shell Tank System Integrity Assessment: \\ FINAL RESULTS OF DOUBLE-SHELL TANK 241-AY-102 ULTRASONIC INSPECTION}

\subsection{INTRODUCTION}

In May 1996, the Tank Waste Remediation System (TWRS) Decision Board recommended, and the U.S. Department of Energy-Richland Operations Office (DOERL) agreed, that the condition of the double-shell tanks (DST) should be determined by ultrasonic (UT) inspection of a limited area in six of the 28 DSTs. The Washington State Department of Ecology (WDOE) has agreed with the strategy of limited UT inspection of six DSTs. Data collected during the UT inspections will be used to assess the condition of the tanks, judge the effects of past corrosion control practices, and satisfy a regulatory requirement to periodically assess the integrity of waste tanks.

In November 1996, the primary and secondary walls of DST 241-AW-103 were remotely examined to determine if Hanford DST walls could be inspected without removing the existing surface rust and scale. The successful completion of this inspection represented the first UT inspection of a Hanford DST (Leshikar 1997).

Based on the results of the initial inspection, a statement of work (SOW)(Pfluger 1999) was prepared for the remaining DST inspections scheduled for Fiscal Year (FY) 1999. The service of COGEMA Engineering Corporation (COGEMA Engineering) was retained to provide an UT examination system (equipment, procedures, and inspectors) and perform the inspection.

Tank 241-AY-102 was selected as one of the six sample tanks that represent the complete 28 -tank population. The tank began receiving waste in 1976 and is currently classified as a dilute waste tank (DN). The current tank level is approximately 185 inches (Hanlon 1999). From 1976 to present, the waste temperature in the tank has not exceeded $123^{\circ} \mathrm{F}$ with the average temperature holding at approximately $68^{\circ} \mathrm{F}$. Although the tanks are expected to have similar performance, the selection of tanks is purposely biased towards tanks whose primary walls may be more likely to be degraded by corrosion. The tank selection criteria (Schwenk and Scott 1996) considered variables that may influence corrosion, such as waste physical characteristics, waste chemistry, temperature, and age. Tank 241-AY-102 was chosen because it is older, had significant waste height fluctuations, and the material of construction is more conducive to cracking in the knuckle region. 


\subsection{OBJECTIVE / SCOPE}

This report presents the results of the UT examination of DST 241-AY -102 with attention focused on the primary tank wall base metal and welds. Issuance of this report meets FY 1999 Performance Agreement TWR 6.3.1. The criteria, deliverables, and responsibilities for the UT examination are described in Pfluger 1999.

\subsection{EXAMINATION EQUIPMENT DESCRIPTION}

P-scan - P-scan is the name of the computerized pulse-echo UT inspection system used by the examination vendor. The P-scan system is manufactured by Force Institute in Denmark. It acquires data from zero and angle beam transducers mounted on the crawler, allows real-time analysis, and records the data in electronic memory for post inspection analysis. Force Institute has designated "P-scan mode" to represent the angle beam (flaw length) view and "T-scan mode" to represent the zero beam (thickness) view. T-scan mode is used for normal operation and, if crack-like indications are detected, the P-scan mode is employed. More information on the procedure for the P-scan system is found in Jensen 1999.

Crawler (UT Scanner) - The crawler is a remotely-controlled device that delivers the ultrasonic sensors to the tank walls (Figure 2). It weighs approximately 30 pounds and has dimensions of approximately 21 " wide $\times 18$ " long $\times 6$ " high. The crawler attaches to the tank wall with two pairs of magnetic wheels. A traveling bridge on the crawler is outfitted with ultrasonic sensors. As the crawler moves slowly forward, the sensors glide from side-to-side over the tank wall surface. Water couplant is continuously fed to each transducer at a rate needed to maintain an acceptable signal.

Overview Camera - This camera was deployed to observe the area immediately around the inspection area and to aid crawler deployment in the annulus.

Sideview Camera - This camera and light system were installed in a riser adjacent to the inspection riser to provide an overall view of the inspection process.

Data Acquisition Control Center - A pull-type trailer was used to house the crawler controls, video monitors, and the data collection and evaluation hardware. The trailer was located outside the AY tank farm boundary fence (Figure 2).

Deployment Tool - This device was specifically designed to insert and retrieve the scanner from the DST annular space. The scanner sits on a platform that is manually lowered to the appropriate elevation. That platform has cables attached that can be controlled to move the scanner platform into contact with the examination surface. The scanner is then driven onto the surface. The deployment tool is retracted until scanner removal is required. 


\subsection{PERFORMANCE DEMONSTRATION TESTS}

Prior to field use, COGEMA Engineering's UT examination system satisfactorily completed a performance demonstration test (PDT). The test was performed prior to examination of tank 241-AN-107 in FY 1998 (Pfluger 1998). The test was conducted to qualify personnel, test procedures, and ensure the equipment's ability to detect and size wall thinning, pits, and cracks in a series of test plates with artificial and natural defects. The PDT was performed on an actual tank mockup located in the 306E facility located in the Hanford site 300 area. This mockup also demonstrated the successful deployment and retrieval of the equipment. Pacific Northwest National Laboratory report (Attachment 1) PNNL-12233 Ultrasonic Examination of Double-Shell Tank 241-AY-102 provides details of the complete examination and brief evaluation of the PDT.

\subsection{ULTRASONIC EXAMINATION DESCRIPTION}

\subsection{Primary Wall and Weld Inspection}

The tank inspection was performed under Job Control System (JCS) work package 2E-98-02406/W during early calendar year 1999. All work steps, guidelines, procedures, personnel responsibilities, and protocol for the inspection (Pfluger 1999) were included in the subject work package.

An updated version of the remotely-controlled, steerable crawler was used to deliver the UT sensors to the tank wall. The crawler was deployed through a 24 -inch annulus inspection riser number $18 \mathrm{~B}$. The crawler attached to the tank wall with two pairs of magnetic wheels. A traveling bridge on the crawler was outfitted with UT sensors. As the crawler moved slowly forward, the sensors glided from side-to-side over the inspection surface. Water couplant was continuously fed to each transducer at a rate needed to attain an acceptable signal. For examination of the wall, one dual element $0^{\circ}$ transducer and two $45^{\circ}$ shear wave transducers were used. To detect cracks perpendicular to welds, two opposing $45^{\circ}$ shear wave transducers were directed parallel to the weld. To detect cracks parallel to the weld, a $60^{\circ}$ shear-wave transducer was directed toward the weld and a dual element $0^{\circ}$ transducer was also included. Welds were examined from both sides of the weld crown.

Data and images from both systems were returned to a control center located just outside the AY tank farm fence (Figure 2). The control center housed the crawler controls, video monitors, and data collection and evaluation software/hardware. The UT inspector continuously monitored the signal for reportable indications. The inspection was viewed by a camera and lighting system deployed in an adjacent riser. 


\subsection{GENERAL REQUIREMENTS AND INSPECTION CRITERIA}

The FY 1999 Performance Agreement TWR 6.3.1 is stated below:

"The contractor shall perform ultrasonic examination of four double-shell tanks (primary walls straight portion) to the extent described in HNF-2820, "Engineering Task Plan for the Ultrasonic Inspection of Hanford Double-Shell Tanks". Completion is met when ultrasonic examination on four double-shell tanks is performed, a report of examinations/observations is reviewed and approved by FDH, and the report is submitted to RL by July 31,1999 . The report shall include the extent of the examination, discussion of observations, findings, and conclusions."

Areas to be examined on the primary tank were identified in the SOW (Pfluger 1999) as:

Primary Tank Wall:

- A vertical strip, approximately 30 inches wide by 35 feet long. The vertical strip may be comprised of one or more strips whose total width is approximately 30 inches. (The distance from the tank upper haunch transition to the lower knuckle is approximately 35 feet).

- 20 feet of the cylinder-to-lower knuckle weld.

- One vertical weld joining the lowest shell course plates (approximately 10 feet).

- One vertical weld joining the next to the lowest shell course plates (approximately 10 feet).

\subsection{INDICATION REPORTING CRITERIA}

COGEMA Engineering was required to report to the customer the following anomalies (Pfluger 1999):

- Wall thinning that exceeded $10 \%$ of the nominal plate thickness

- Pit depths that exceeded $25 \%$ of the nominal wall thickness

- Cracks that exceeded 0.18 inches in depth. 


\subsection{EQUIPMENT SET-UP AT AY TANK FARM}

Prior to performing the actual examination, the riser shield plug was removed and replaced with a sheetmetal cover.

A temporary structure, constructed of scaffolding, was erected around the riser to provide the means for deploying the UT equipment (Figure 2). A central I-Beam was secured to the top of the scaffolding and supported a single-line sheave. A manual cable winch was secured to the base with the cable running up to the sheave in a single-line hoisting method for maneuvering the equipment into position. The weather during the examination was cool to moderate so a second temporary structure was erected near the inspection riser. This "tent" was constructed of round tubing and covered with weather resistant material and housed the inspection overview video equipment, deployment tool and video monitor (Figure 2). The tent provided adverse weather protection for the equipment and crew. The control cables leading from the trailer were run along the ground to the equipment located at the riser. The cable was sleeved with plastic to prevent possible contamination

\subsection{EXAMINATION RESULTS}

The Inspection Data Sheets and an interpretation of the data by a COGEMA Engineering Level III qualified inspector are included in Attachment 2. Tank 241-AY-102 (typical of all double-shell tanks) was fabricated from carbon steel plate. The location of plates as identified in the PNNL report is as follows (See Attachment 1):

Primary knuckle (top) - Connects dome of tank to side-wall. Primary wall - Consists of (from top to bottom):

Top Transition Plate - approximately 3 feet, 3 inches tall, 3/8" nominal thickness

Plate \#1 - approximately 9 feet, 10 inches tall, $1 / 2$ " nominal thickness

Plate \#2 - approximately 9 feet, 10 inches tall, $1 / 2$ " nominal thickness

Plate \#3 - approximately 9 feet tall, $3 / 4$ " nominal thickness

Primary knuckle (bottom) - Connects side-wall of tank to primary tank bottom.

All tank welds are in the "as-welded" condition. The primary tanks exterior surface varies from mill scale to a coating of rust caused by the normal weathering of carbon steel. The tank surface also contains chalk marks from hydrostatic test and miscellaneous material identifier markings from construction. In some places, streaks from concrete pouring can be found.

The following pages contain tables that present the data as a percent (\%) of nominal wall thickness, which was derived from the "241-AY-102 Double-Shell Tank Ultrasonic Examination Data Reports With Data Sheets" (Attachment 2) and Pacific Northwest National Laboratory report PNNL-12233 (Attachment 1) "Ultrasonic Examination of Double-Shell Tank 241-AY-102". 
Table 1

Tank 241-AY-102 Ultrasonic Examination

Primary Tank Wall, Scan 1 (Attachment 2)

\begin{tabular}{|c|c|c|c|}
\hline Plate & $\begin{array}{c}\text { Design } \\
\text { Nominal Thickness } \\
\text { (inches) }\end{array}$ & $\begin{array}{c}\text { Measured } \\
\text { Minimum Thickness } \\
\text { (inches) }\end{array}$ & \% Wall Thinning \\
\hline Plate \#1 & 0.375 & 0.395 & N/A \\
\hline Plate \#2 & 0.50 & 0.495 & $1.0 \%$ of nominal thickness \\
\hline Plate \#3 & 0.50 & 0.495 & $1.0 \%$ of nominal thickness \\
\hline Plate \#4 & 0.75 & 0.735 & $2.0 \%$ of nominal thickness \\
\hline
\end{tabular}

\section{Table 2}

Tank 241-AY-102 Ultrasonic Examination

Primary Tank Wall, Scan 2 (Attachment 2)

\begin{tabular}{|c|c|c|c|}
\hline Plate & $\begin{array}{c}\text { Design } \\
\text { Nominal Thickness } \\
\text { (inches) }\end{array}$ & $\begin{array}{c}\text { Measured } \\
\text { Minimum Thickness } \\
\text { (inches) }\end{array}$ & \% Wall Thinning \\
\hline Plate \#1 & 0.375 & 0.383 & N/A \\
\hline Plate \#2 & 0.50 & 0.485 & $3.0 \%$ of nominal thickness \\
\hline Plate \#3 & 0.50 & 0.485 & $3.0 \%$ of nominal thickness \\
\hline Plate \#4 & 0.75 & 0.734 & $2.1 \%$ of nominal thickness \\
\hline
\end{tabular}


Table 3

Tank 241-AY-102 Ultrasonic Examination

Horizontal and Vertical Primary Tank Weld Scans (Attachment 2)

\begin{tabular}{|c|c|c|c|}
\hline Weld & $\begin{array}{c}\text { Design } \\
\text { Nominal Thickness } \\
\text { (inches) }\end{array}$ & $\begin{array}{c}\text { Measured } \\
\text { Minimum Thickness } \\
\text { (inches) }\end{array}$ & $\begin{array}{c}\% \text { Wall } \\
\text { Thinning }\end{array}$ \\
\hline Vertical Plate \#3 & 0.50 & 0.465 & $7 \%$ of nominal thickness \\
\hline Vertical Plate \#4 & 0.750 & 0.722 & $3.7 \%$ of nominal thickness \\
\hline $\begin{array}{c}\text { Horizontal } \\
\text { \#2and \#3 }\end{array}$ & 0.50 & 0.485 & \\
\hline
\end{tabular}

Note 1: PNNL evaluated the data and concluded that no wall thinning, pitting, or cracking is present. Refer to PNNL-12233 Ultrasonic Examination of Double Shell Tank 241-AY102 (see Attachment 1).

Note 2: Although the data is reported to three decimal places, the accuracy of the data, based on the results of the performance demonstration test is \pm 0.020 inch for wall thickness.

\subsection{EVALUATION OF EXAMINATION RESULTS}

The results of the Tank 241-AY-102 UT examination indicated no reportable wall thinning, pitting, or cracks. Attachment 1 contains the report prepared by PNNL that analyzes the data gathered from Tank 241-AY-102 UT examination. Figure 1 shows the history of waste level matched with the "as-found" measurements of the primary tank wall generated from the inspection data sheets (Attachment 2). Each wall thickness measurement plotted on the figure is the average of all data collected over a 1 -foot long by 15 -inch wide scan area. No apparent wall thinning, pitting, and cracking.

PNNL UT examination experts independently evaluated (Attachment 1) the hard copy scans and inspection data sheets and concurred with the COGEMA Engineering interpretation (see Attachment 2). The following is a summary of the results associated with the areas examined. The data have been reviewed and approved by W. H. Nelson, COGEMA Engineering Level III qualified inspector (Attachment 2):

Primary Tank Wall Thinning/Pitting/Cracking:

- No reportable thinning, pitting, or cracking was detected. 
Primary Tank Horizontal and Vertical Welds:

- No reportable thinning, pitting, or cracking was detected.

- Scans of the heat affected zones (HAZ) between Plate \#2 and \#3 revealed no pitting, or crack-like indications.

- Welds between Plate \#3 and \#4 and the lower knuckle weld could not be examined because of surface roughness and contamination (weld and concrete splatter)

\section{$11.0 \quad$ FINDINGS AND CONCLUSIONS}

- The absence of cracks in the plate and HAZ indicates that the pre-service material quality control, weld stress relief treatment, and waste chemistry controls have been effective in preventing cracks.

- Since there were no significant changes in the wall thickness and no cracks were detected at any location, corrosion due to suspected mechanisms is probably not occurring to any significant degree. However, uncertainty on conditions that lead to corrosion degradation, particularly stress corrosion cracking, suggest additional data on other tanks are needed to gain confidence that this result can be applied to the general tank population. 


\subsection{REFERENCES}

Hanlon, B.M., 1999, Waste Tank Summary Report for Month Ending April 30, 1999, HNF-EP-0182-121, Fluor Daniel Hanford, Inc., Richland, Washington.

Jensen, C. E., 1999, Final Results of Double-Shell Tank 241-AN-105 Ultrasonic Inspection, HNF-4816, Rev. 0, Lockheed Martin Hanford Corporation, Richland, Washington

Leshikar, G.A., 1997, Final Report - Ultrasonic Examination of Tank 241-AW-103 Walls, HNF-SD-WM-TRP-282, Rev. 1, SGN Eurisys Services Corporation, Richland, Washington.

Pfluger, D.C., 1998, Final Results of Double-Shell Tank 241-AN-107 Ultrasonic Inspection, HNF-3353, Rev. 0, Lockheed Martin Hanford Corporation, Richland, Washington

Pfluger, D.C., 1999, Engineering Task Plan for the Ultrasonic Inspection of Hanford Double-Shell Tanks, HNF-2820, Rev. 1, Lockheed Martin Hanford Corporation, Richland, Washington

Schwenk, E.B., and Scott, K.V., 1996, Description of Double-Shell Tank Selection Criteria for Inspection, WHC-SD-WM-ER-529, Rev. 0, Westinghouse Hanford Company, Richland, Washington. 


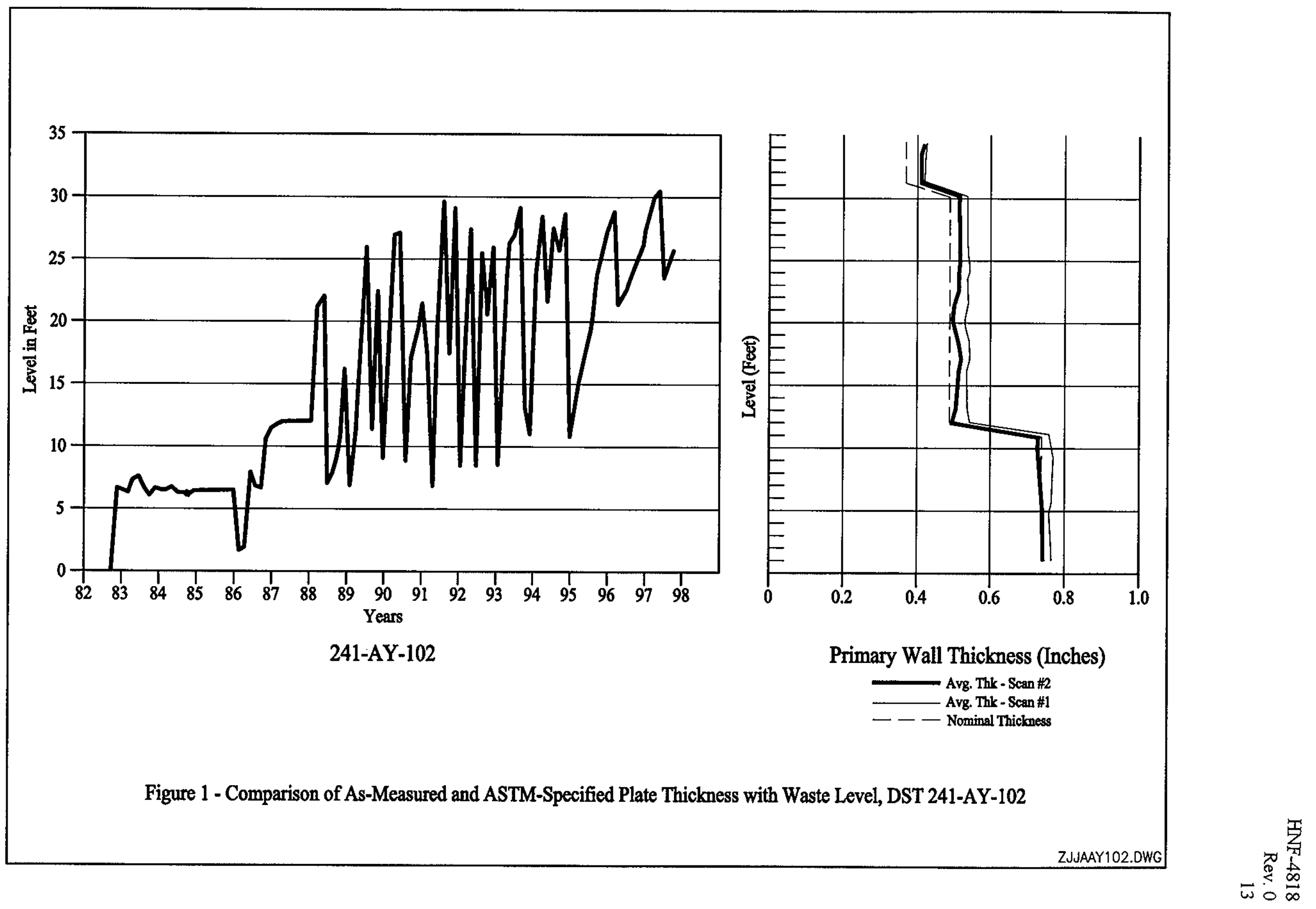




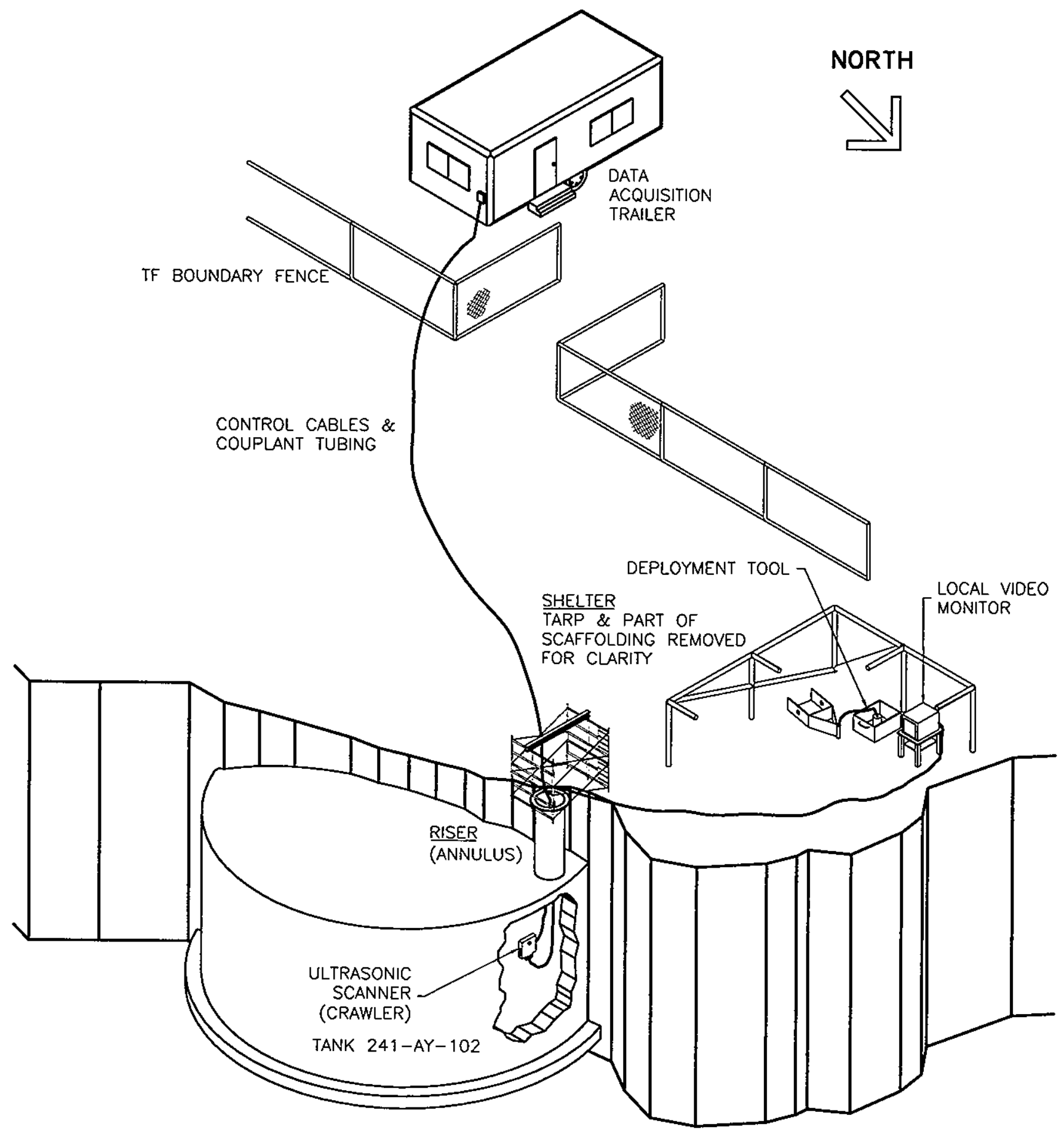

Figure 2 - Schematic of Inspection Set-up 241-AY-102 


\section{ATTACHMENT 1}

Ultrasonic Examination of Double Shell Tank 241-AY-102

PNNL-12233 


\title{
Ultrasonic Examination of Double Shell Tank 241-AY-102
}

\author{
G. J. Posakony
}

A. F. Pardini

June 1999

Prepared for

Lockheed Martin Hanford Corporation

Richland, Washington 99352

Pacific Northwest National Laboratory Richland, Washington 99352 


\section{Summary}

COGEMA Engineering Corporation (COGEMA), under a contract from Lockheed Martin Hanford Corporation (LMHC), performed an ultrasonic examination of selected portions of Tank 241-AY-102. The purpose of this examination was to provide information that could be used to evaluate the integrity of the wall of the primary tank. To implement the examination, COGEMA contracted with Swain Distribution, Inc. (Swain) of Searcy, Arkansas for the qualified personnel, ultrasonic instrumentation, and remote-controlled mechanical crawler that were to be used in performing this examination. The equipment provided by Swain included the Force Industries, Inc. P-Scan Model PSP-3 ultrasonic flaw detector system and the Force Industries AWS-5D remote, digitally controlled, magnetic-wheel mechanical crawler. The P-Scan Model PSP-3 is the same ultrasonic system used in the inspections of Tanks 241-AW-103, AN-105, and AN-107, but the magnetic wheel crawler was upgraded to Model AWS-5D. The ultrasonic procedure for the examination of the double-shell tanks at Hanford was developed by Swain personnel and approved by Mr. Wesley Nelson. Mr. Nelson is COGEMA's American Society for Nondestructive Testing (ASNT) Certified Level III in ultrasonic testing (UT) and was the UT Level III authority for this project.

Reports PNNL-11971 and PNNL-12198 provide details on the examination requirements, ultrasonic inspection procedure, personnel qualification requirements, and the results from AN-107 and AN-105. For details and information on the performance demonstration test (PDT), please refer to the referenced PNNL reports.

The ultrasonic examination of Tank 241-AY-102 was designed to inspect the wall of the primary tank to detect wall thinning, pit corrosion, and cracks in the tank wall as well as cracks, wall thinning, and other anomalies in the heat-affected zone (HAZ) of vertical, horizontal, and knuckle welds. In Tank 241-AY-102 selected portions of the primary tank wall were examined and these results were used as a representative sampling of conditions in the remainder of the primary tank.

Figure S.1 is a sketch of the portions of Tank 241-AY-102 that were ultrasonically examined. The wall of the primary tank is $32-\mathrm{ft}$ high and is made up of four rings of plates that have been welded together. The ultrasonic examination consisted of inspecting two 15-in.-wide vertical strips the full 32-ft height of the tank to detect wall thinning and any cracking or other anomalies that might be in the wall of the primary tank. In addition, the weld zones of selected vertical and horizontal welds were inspected to detect and characterize any cracks that might lie parallel or perpendicular to the welds. The sketch shows the vertical scan paths for the two ultrasonic plate thickness and plate crack examinations. These scans were separated by approximately 6-in. The sketch also shows the top weld (primary tank to dome weld), vertical and horizontal welds, and knuckle weld. In performing the examinations, the remote-controlled, magnetic wheel crawler was installed in the annulus of the double-shell tank through the 24-in, riser. 


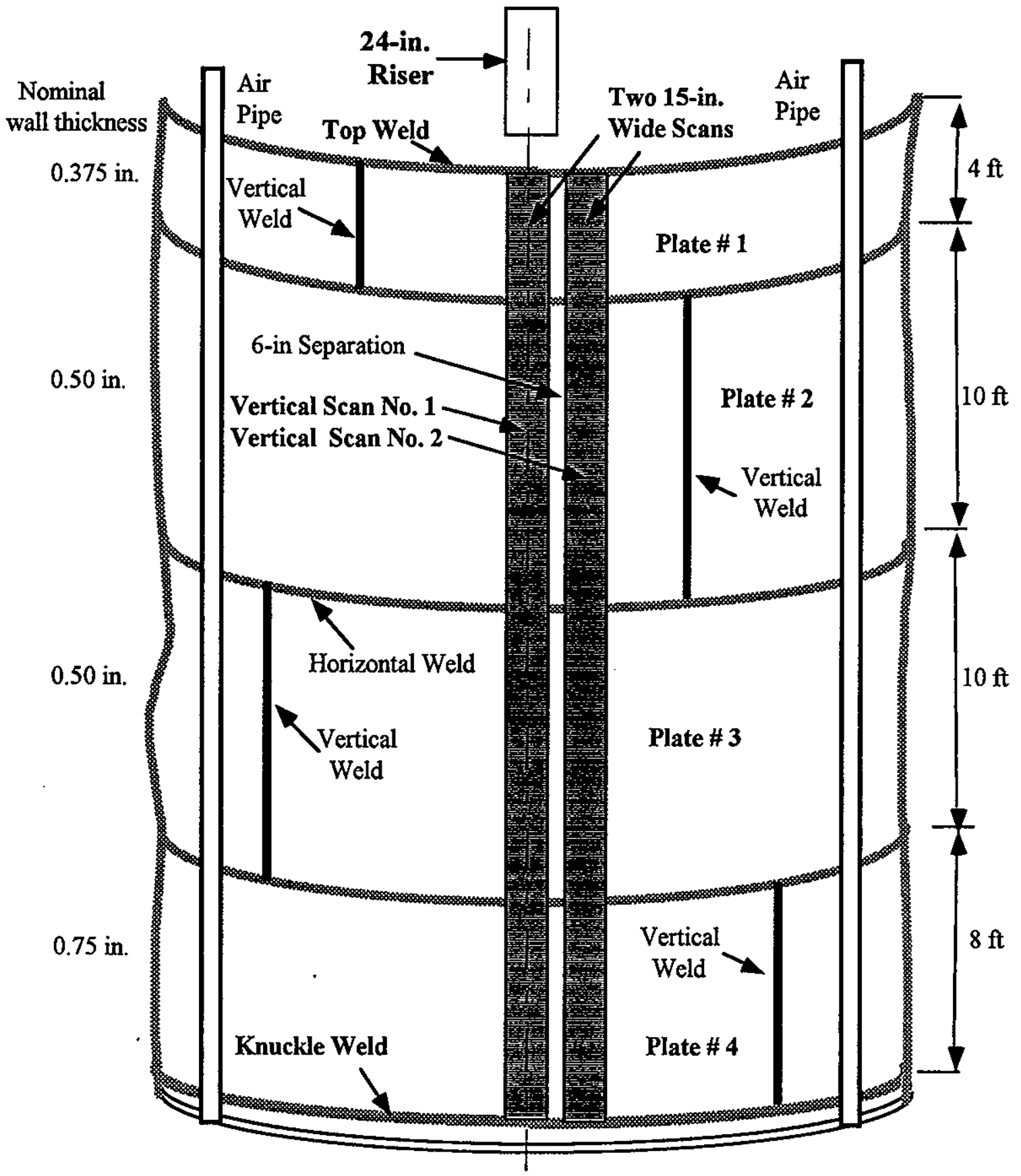

Figure S.1. Sketch of Vertical Scan Paths No. 1 and No. 2 Used for the Ultrasonic Examination of the Primary Tank Wall of 241-AY-102 
The shell of Tank 241-AY-102 consists of four cylindrical rings. The top ring (Plate \#1) is 4-ft high and has a nominal wall thickness of 0.375 in. The second and third rings (Plate \#2 and Plate \#3) are 10-ft high and have a nominal wall thickness of 0.500 in. Plate \#4 is 8-ft high and has a nominal wall thickness of 0.75 in. ${ }^{(a)}$

Two separate ultrasonic examinations were made for each of the scan paths of the tank wall shown in Figure S.1. The first examination (0-degree, straight-beam transducer) was designed to detect wall thinning and the presence of cracks. The second examination ( \pm 45 -degree, angle-beam transducers) was designed to characterize any cracking that might be present in the wall of the primary tank.

A summary of the results is given below. More details are found in the body of the report.

- Plate \#1-Scan Paths No. 1 and No. 2-the first examination of this plate recorded wall thickness (nominal 0.375 in.) ranging from a minimum of 0.383 in. to a maximum of 0.405 in. In the second examination, neither scan detected crack-like indications were in the wall of the primary tank.

- Plate \#2-Scan Paths No. 1 and No. 2-the first examination of this plate recorded wall thickness (nominal $0.500 \mathrm{in}$.) ranging from a minimum of $0.485 \mathrm{in}$. to a maximum of $0.514 \mathrm{in}$. In the second examination, neither scan detected crack-like indications were in the wall of the primary tank.

- Plate \#3-Scan Paths No. 1 and No. 2-the first examination of this plate recorded wall thickness (nominal $0.500 \mathrm{in}$.) ranging from a minimum of $0.485 \mathrm{in}$. to a maximum of $0.518 \mathrm{in}$. In the second examination, neither scan detected crack-like indications were in the wall of the primary tank.

- Plate \#4-Scan Paths No. 1 and No. 2-the first examination of this plate recorded wall thickness (nominal $0.75 \mathrm{in}$.) ranging from a minimum of $0.735 \mathrm{in}$. to a maximum of $0.748 \mathrm{in}$. In the second examination, neither scan detected crack-like indications were in the wall of the primary tank.

- Several feet of vertical welds in Plates \#3 and \#4 were examined with 0 -degree, \pm 45 -degree and 60-degree transducers. No crack-like indications, wall thinning or pitting was detected in the HAZ of the welds in these examinations.

- Twenty feet of horizontal weld between Plates \#2 and \#3 were examined using the same technique used for the vertical welds. No crack-like indications, wall thinning or other indications were found in the HAZ of this weld.

- Welds between Plate \#3 and \#4 and the lower knuckle weld could not be examined because of surface roughness and contamination (weld and concrete splatter).

(a) Note: All historical dimensioning for the design, development, and construction of this tank are in English units; consequently, English units are the primary units used in this report. For conversion to metric, use 1.0 in. equals $25.4 \mathrm{~mm}$. 


\section{Contents}

Summary

iii

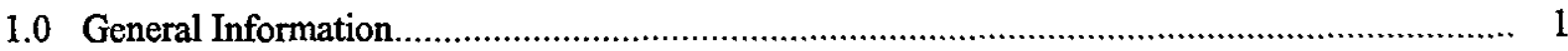

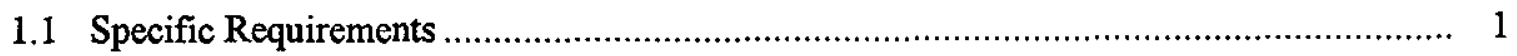

2.0 Results of the Examinations of the Vertical Wall of the Primary Tank 241-AY-102 ............. 1

3.0 Results Recorded in the Examination of Selected Vertical and Horizontal Welds .................. 5

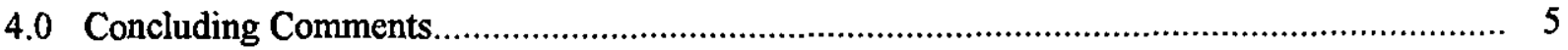

\section{Figures}

S.1 Sketch of Vertical Scan Paths No. 1 and No. 2 Used for the Ultrasonic Examination of the Primary Tank Wall.

iv

\section{Tables}

1. Data from the Vertical UT Scan Paths on the Primary Tank Wall, Plate \#1 ............................. 3

2. Data from the Vertical UT Scan Paths on the Primary Tank Wall, Plate \#2 ............................. 3

3. Data from the Vertical UT Scan Paths on the Primary Tank Wall, Plate \#3 ............................. 4

4. Data from the Vertical UT Scan Paths on the Primary Tank Wall, Plate \#4 .............................. 4 


\subsection{General Information}

The requirements for the ultrasonic examination of the wall of Tank 241-AY-102 were to detect, characterize (identify, size, and locate) and record measurements made of wall thickness, pitting or cracking in the wall or in the heat-affected zone (HAZ) of the welds in the primary tank. Any conditions that exceeded the requirements set forth below were to be reported for further examination.

\subsection{Specific Requirements}

Measurements that are to be specifically recorded include the following:

- Wall thinning that exceeds $10 \%$ of the nominal thickness of the plate

- Pits with depths that exceed $25 \%$ of the plate thickness

- Stress-corrosion cracks located on the inner wall of the primary tank or in the HAZ of welds that exceed a depth of 0.18 in.

The accuracy requirements for depth measurements for the different types of defects includes:

- Wall thinning-measure thickness within \pm 0.02 in.

- Pits-size depths within \pm 0.05 in.

- Cracks-size the depth of cracks on the inner wall surfaces within \pm 0.100 in.

- Location-locate all reportable indications within $\pm 1.0 \mathrm{in}$. LMHC.

Data to be recorded on disk and hard copies of all measurements are to be provided to PNNL and

\subsection{Results of the Examinations of the Vertical Wall of the Primary Tank 241-AY-102}

Figure S.1 shows the two vertical scan paths taken on the full height of the tank. Each of the paths was 15-in. wide, providing a total of 30-in. coverage of the cylindrical section of the tank for the full height (32-ft) from the top weld to the knuckle weld. Two separate 15-in. wide scans (traverse direction on the scanning bridge of the mechanical crawler) were made. The first examination provided a measurement of wall thinning and/or pit corrosion using a straight beam (0-degree) transducer. The 
second examination used two 45-degree opposing transducers and provided information on any cracks in the plates of the wall of the primary tank. Tables 1 through 4 describe the results of the two vertical examinations of the primary tank wall.

To initiate the examination, the remote mechanical crawler was inserted through the 24-in. riser and lowered until the magnetic wheels attached to the wall of the primary tank. The examination was then initiated by maneuvering the remote crawler until the transducer(s) were positioned at the top weld between the tank shell and the dome. The mechanical scanner was programmed to traverse a 15 -in. scan, index down the tank wall and repeat the sequence until the entire height of the tank was examined. Pressurized water was used as a couplant between the transducer and the tank wall. The scan index (down the vertical wall) was $0.10 \mathrm{in}$. There were 120 traverse scans were taken for every foot of the height of the tank. The encoder on the scanner divided the 15 -in. length of the traverse scan into pixels estimated to be 0.125 -in. wide or 120 pixels. The ultrasonic data acquisition system recorded 14400 pixels for every foot of vertical scan path. Hard copy information was provided on an ultrasonic C-scan plot for each 12 by 15 -in. area scanned. The analyst used this information in conjunction with the software program to determine and record the minimum value in each 12 by 15 -in. area. The values in Tables 1 through 4 are the minimum values recorded in each area for the two scan paths. These values are part of the data recorded by the analyst on the "Automated Thickness Data Report." While only the minimum thickness is recorded on these reports, data are available to measure any individual pixel or point in the area scanned. In addition to the minimum thickness value reported, the tables also provide information regarding the results of the angle-beam examination that was designed to detect any cracking that might have been present in the tank wall. In the angle beam examination, two 45-degree angle-beam transducers were used. These angle-beam transducers were separated by approximately $5 \mathrm{in}$. and their beams were directed toward one another to obtain a volumetric inspection of the tank wall.

The tables provide information on the distance down from the top weld and the results obtained from the ultrasonic examination at each level. Interpreting the data in Table 1 from Plate \#1, in the 1-ft section below the top weld (between the shell and the dome) the minimum thickness recorded was 0.398 in. in Scan Path No. 1 and 0.405 in Scan Path No. 2. The minimum wall thickness recorded in this 4-ft transition plate in Scan Path No. 2 between 2 and $3 \mathrm{ft}$. from the top weld where a value of 0.383 was measured. The nominal wall thickness was reported to be 0.375 in. and all thicknesses measured were above this value. The results of the 45-degree angle-beam examination recorded in the table showed no crack-like indications in either scan. Similar data interpretation can be made in the Tables 2, 3, and 4.

A review of the information in the tables shows that no anomalous conditions were detected by the ultrasonic examination. It is believed that these results are a representative sampling of the condition in the wall of the primary tank. No examination was performed on other portions of the primary or secondary tanks. 
Table 1. Data from the Vertical UT Scan Paths on the Primary Tank Wall, Plate \#1

\begin{tabular}{|c|c|c|c|c|}
\hline \multirow[b]{2}{*}{$\begin{array}{l}\text { Distance } \\
\text { from the } \\
\text { Top Weld } \\
\text { (ft) }\end{array}$} & \multicolumn{2}{|c|}{$\begin{array}{l}\text { Results from the Ultrasonic } \\
\text { Examination of Plate } \# 1 \text {. } \\
\text { Vertical Scan Path No. } 1\end{array}$} & \multicolumn{2}{|c|}{$\begin{array}{l}\text { Results from the Ultrasonic } \\
\text { Examination of Plate \#1. } \\
\text { Vertical Scan Path No. } 2\end{array}$} \\
\hline & $\begin{array}{l}\text { Minimum } \\
\text { Thickness } \\
\text { Recorded in Area } \\
\text { Scanned (in.) }\end{array}$ & $\begin{array}{l}\text { 45-Degree } \\
\text { Angle Beam } \\
\text { Examination }\end{array}$ & $\begin{array}{l}\text { Minimum } \\
\text { Thickness } \\
\text { Recorded in Area } \\
\text { Scanned (in.) }\end{array}$ & $\begin{array}{l}\text { 45-Degree } \\
\text { Angle Beam } \\
\text { Examination }\end{array}$ \\
\hline 0 to 1 & 0.398 & \multirow{4}{*}{$\begin{array}{l}\text { No crack-like } \\
\text { indications } \\
\text { were detected } \\
\text { in this plate }\end{array}$} & 0.405 & \multirow{4}{*}{$\begin{array}{l}\text { No crack-like } \\
\text { indications } \\
\text { were detected } \\
\text { in this plate }\end{array}$} \\
\hline 1 to 2 & 0.398 & & 0.395 & \\
\hline 2 to 3 & 0.395 & & 0.383 & \\
\hline 3 to 4 & 0.398 & & 0.390 & \\
\hline
\end{tabular}

Table 2. Data from the Vertical UT Scan Paths on the Primary Tank Wall, Plate \#2

\begin{tabular}{|c|c|c|c|c|}
\hline \multirow[b]{2}{*}{$\begin{array}{c}\text { Distance } \\
\text { from the } \\
\text { Top Weld } \\
\text { (ft) }\end{array}$} & \multicolumn{2}{|c|}{$\begin{array}{l}\text { Results from the Ultrasonic } \\
\text { Examination of Plate } \# 2 \text {. } \\
\text { Vertical Scan Path No. } 1\end{array}$} & \multicolumn{2}{|c|}{$\begin{array}{l}\text { Results from the Ultrasonic } \\
\text { Examination of Plate \#2. } \\
\text { Vertical Scan Path No. } 2\end{array}$} \\
\hline & $\begin{array}{c}\text { Minimum } \\
\text { Thickness } \\
\text { Recorded in Area } \\
\text { Scanned (in.) }\end{array}$ & $\begin{array}{c}\text { 45-Degree } \\
\text { Angle Beam } \\
\text { Examination }\end{array}$ & $\begin{array}{l}\text { Minimum } \\
\text { Thickness } \\
\text { Recorded in Area } \\
\text { Scanned (in.) }\end{array}$ & $\begin{array}{l}\text { 45-Degree } \\
\text { Angle Beam } \\
\text { Examination }\end{array}$ \\
\hline 4 to 5 & 0.495 & \multirow{10}{*}{$\begin{array}{l}\text { No crack-like } \\
\text { indications } \\
\text { were detected } \\
\text { during the } \\
\text { examination } \\
\text { of this plate }\end{array}$} & 0.493 & \multirow{10}{*}{$\begin{array}{l}\text { No crack-like } \\
\text { indications } \\
\text { were detected } \\
\text { during the } \\
\text { examination } \\
\text { of this plate }\end{array}$} \\
\hline 5 to 6 & 0.500 & & 0.493 & \\
\hline 6 to 7 & 0.510 & & 0.495 & \\
\hline 7 to 8 & 0.510 & & 0.498 & \\
\hline 8 to 9 & 0.503 & & 0.498 & \\
\hline 9 to 10 & 0.503 & & 0.498 & \\
\hline 10 to 11 & 0.508 & & 0.493 & \\
\hline 11 to 12 & 0.518 & & 0.490 & \\
\hline 12 to 13 & 0.514 & & 0.485 & \\
\hline 13 to 14 & 0.514 & & 0.493 & \\
\hline
\end{tabular}


Table 3. Data from the Vertical UT Scan Paths on the Primary Tank Wall, Plate \#3

\begin{tabular}{|c|c|c|c|c|}
\hline \multirow[b]{2}{*}{$\begin{array}{l}\text { Distance } \\
\text { from the } \\
\text { Top Weld } \\
\text { (ft) }\end{array}$} & \multicolumn{2}{|c|}{$\begin{array}{l}\text { Results from the Ultrasonic } \\
\text { Examination of Plate \#3. } \\
\text { Vertical Scan Path No. } 1 \\
\end{array}$} & \multicolumn{2}{|c|}{$\begin{array}{l}\text { Results from the Ultrasonic } \\
\text { Examination of Plate } \# 3 . \\
\text { Vertical Scan Path No. } 2\end{array}$} \\
\hline & $\begin{array}{c}\text { Minimum } \\
\text { Thickness } \\
\text { Recorded in Area } \\
\text { Scanned (in.) } \\
\end{array}$ & $\begin{array}{c}\text { 45-Degree } \\
\text { Angle Beam } \\
\text { Examination }\end{array}$ & $\begin{array}{c}\text { Minimum } \\
\text { Thickness } \\
\text { Recorded in Area } \\
\text { Scanned (in.) } \\
\end{array}$ & $\begin{array}{l}\text { 45-Degree } \\
\text { Angle Beam } \\
\text { Examination }\end{array}$ \\
\hline 14 to 15 & 0.500 & \multirow{10}{*}{$\begin{array}{l}\text { No crack-like } \\
\text { indications } \\
\text { were detected } \\
\text { during the } \\
\text { examination } \\
\text { of this plate }\end{array}$} & 0.490 & \multirow{10}{*}{$\begin{array}{l}\text { No crack-like } \\
\text { indications } \\
\text { were detected } \\
\text { during the } \\
\text { examination } \\
\text { of this plate }\end{array}$} \\
\hline 15 to 16 & 0.518 & & 0.485 & \\
\hline 16 to 17 & 0.510 & & 0.490 & \\
\hline 17 to 18 & 0.508 & & 0.488 & \\
\hline 18 to 19 & 0.508 & & 0.490 & \\
\hline 19 to 20 & 0.508 & & 0.490 & \\
\hline 20 to 21 & 0.503 & & 0.490 & \\
\hline 21 to 22 & 0.498 & & 0.490 & \\
\hline 22 to 23 & 0.495 & & 0.493 & \\
\hline 23 to 24 & 0.510 & & 0.498 & \\
\hline
\end{tabular}

Table 4. Data from the Vertical UT Scan Paths on the Primary Tank Wall, Plate \#4

\begin{tabular}{|c|c|c|c|c|}
\hline \multirow[b]{2}{*}{$\begin{array}{l}\text { Distance } \\
\text { from the } \\
\text { Top Weld } \\
\text { (ft) }\end{array}$} & \multicolumn{2}{|c|}{$\begin{array}{l}\text { Results from the Ultrasonic } \\
\text { Examination of Plate \#4. } \\
\text { Vertical Scan Path No. } 1\end{array}$} & \multicolumn{2}{|c|}{$\begin{array}{l}\text { Results from the Ultrasonic } \\
\text { Examination of Plate \#4. } \\
\text { Vertical Scan Path No. } 2\end{array}$} \\
\hline & $\begin{array}{c}\text { Minimum } \\
\text { Thickness } \\
\text { Recorded in Area } \\
\text { Scanned (in.) } \\
\end{array}$ & \begin{tabular}{c|} 
45-Degree \\
Angle Beam \\
Examination \\
\end{tabular} & $\begin{array}{c}\text { Minimum } \\
\text { Thickness } \\
\text { Recorded in Area } \\
\text { Scanned (in.) } \\
\end{array}$ & $\begin{array}{l}\text { 45-Degree } \\
\text { Angle Beam } \\
\text { Examination }\end{array}$ \\
\hline 24 to 25 & 0.735 & \multirow{8}{*}{$\begin{array}{l}\text { No crack-like } \\
\text { indications } \\
\text { were detected } \\
\text { during the } \\
\text { examination } \\
\text { of this plate }\end{array}$} & 0.739 & \multirow{8}{*}{$\begin{array}{l}\text { No crack-like } \\
\text { indications } \\
\text { were detected } \\
\text { during the } \\
\text { examination } \\
\text { of this plate }\end{array}$} \\
\hline 25 to 26 & 0.748 & & 0.739 & \\
\hline 26 to 27 & 0.757 & & 0.743 & \\
\hline 27 to 28 & 0.739 & & 0.743 & \\
\hline 28 to 29 & 0.744 & & 0.743 & \\
\hline 29 to 30 & 0.748 & & 0.734 & \\
\hline 30 to 31 & 0.744 & & 0.739 & \\
\hline 31 to 32 & 0.739 & & 0.743 & \\
\hline
\end{tabular}




\subsection{Results Recorded in the Examination of Selected Vertical and Horizontal Welds}

An ultrasonic examination was performed to detect stress corrosion cracks, wall thinning and pitting in the HAZ of a selected number of welds. Since stress corrosion cracks could lie perpendicular or parallel to the weld line, two separate examinations were performed. The first examination used a pair of 45-degree opposing transducers to detect and characterize cracks that might lie perpendicular to the weld line. In the second examination a straight beam (0-degree) transducer was used to detect wall thinning and corrosion, and a 60-degree transducer was used to detect and characterize cracks that might lie parallel to the weld line. The HAZ was defined as that area that lies on the inner $3 / 4 \mathrm{~T}$ (thickness) of the plate and extending $1.0 \mathrm{in}$. from the edge of the weld bead. The following lists the welds that were examined. Because of interference between the transducer housing and the weld bead, a blind zone existed from the edge of the weld bead to $1 / 2$ in. into the base metal.

- Vertical weld in Plate \#3-10 $\mathrm{ft}$ of the $\mathrm{HAZ}$ of this plate was examined with the 0 -degree, 45-degree and 60-degree transducers. No crack-like indications, wall thinning or pitting was detected in any of the examinations.

- Vertical weld in Plate \#4-9 $\mathrm{ft}$ of the HAZ of this plate was examined with the 0 -degree, 45-degree and 60-degree transducers. No crack-like indications, wall thinning or pitting was detected in any of the examinations.

- Horizontal weld between Plates \#2 and \#3-24 ft of the horizontal weld between Plates \#2 and \#3 were examined with the 0 -degree, 45 -degree and 60 -degree transducers. No crack-like indications, wall thinning or pitting was detected in any of these examinations.

Comment \#1: The horizontal weld between Plates \#3 and \#4 could not be examined ultrasonically because of surface roughness, weld spatter, and other conditions on the surface of the plate in the $\mathrm{HAZ}$ that prevented the transducers from maintaining ultrasonic contact with the plate.

Comment \#2: The knuckle weld could not be examined ultrasonically because of the concrete spatter on the surface of the tank in the weld area that caused the transducer to lift off the surface and prevented consistent ultrasonic coupling of the acoustic energy.

\subsection{Concluding Comments}

The two 15-in. wide ultrasonic examinations were made on the full height of the primary tank wall of Tank 241-AY-102 to detect wall thinning, pitting and cracks. These examinations in the vertical tank wall were intended to sample the condition of the tank and to provide information that could be used to 
establish the tank's integrity. The results of the examinations in the selected areas showed very little or no corrosion in the four plates that go to make up the shell of the primary tank. Further, no crack-like indications were detected in the wall of the primary tank.

The HAZ of the vertical welds in Plates \#3 and \#4 and the horizontal weld between Plates \#2 and \#3 were examined to detect stress-corrosion cracks, pitting, and wall thinning. The ultrasonic examination did not detect wall thinning in excess of $4 \%$ of the nominal wall thickness in the HAZ and found no crack-like indications from cracks that might lie in either parallel or perpendicular to the weld line. No abnormal indications were found in the heat-affected zone of the welds examined.

Based on the results of the ultrasonic examinations in the areas examined, Tank 241-AY-102 has no apparent wall thinning greater than the nominal wall thickness that might be expected from manufacturing variations and has no detectable cracks in the wall of the primary tank. 


\section{ATTACHMENT 2}

241-AY-102 Double-Shell Tank Ultrasonic Examination Data Reports With Data Sheets

COGEMA-99-1017 
June 30,1999

COGEMA-99-1017

Mr. Chris E. Jensen

Lockheed Martin Hanford Corporation

Post Office Box 1500, MSIN R1-56

Richland, Washington 99352-1505

Dear Mr. Jensen:

\section{AX-102 DOUBLE SHELL TANK ULTRASONIC EXAMINATION DATA REPORTS}

Ultrasonic examination of double shell tank (DST) AY-102 was completed on June 4,1999. The primary tank data showed no reportable indications. Primary tank wall areas ultrasonically inspected were two vertical wall scans approximately 15 inches wide by 30 feet long, and 19 feet of the vertical weld and 25 feet of horizontal welds.

The project specification required an ultrasonic inspection of the horizontal weld between the bottom transition plate and the knuckle. However due to concrete material adhered to the inspection surface examination of the weld was not possible. With LMHC concurrence the horizontal weld between plates 1 and 2 was substituted for the weld between the bottom transition plate and the knuckle.

COGEMA Engineering is pleased to provide the enclosed AY-102 DST Ultrasonic Examination Calibration Sheets and Ultrasonic Data Reports. This completes our nondestructive examination of DST AY-102. The original ultrasonic report was transferred to Mr. Jerry Posakony at PNNL for final evaluation.

If you have any questions, please feel free to contact me at (509) 376-5403.

Sincerely,

Wo Deh

W. H. Nelson

COGEMA NDE Uitrasonic Level III

cjl

\section{Enclosure}

P.O. Box 840

Richland, Washington 99352.0840

Phone (509) 372-3572 - Fax (509) 372-3169

U:NelsonDST UTL2sonie/COCEMA-99-1012 


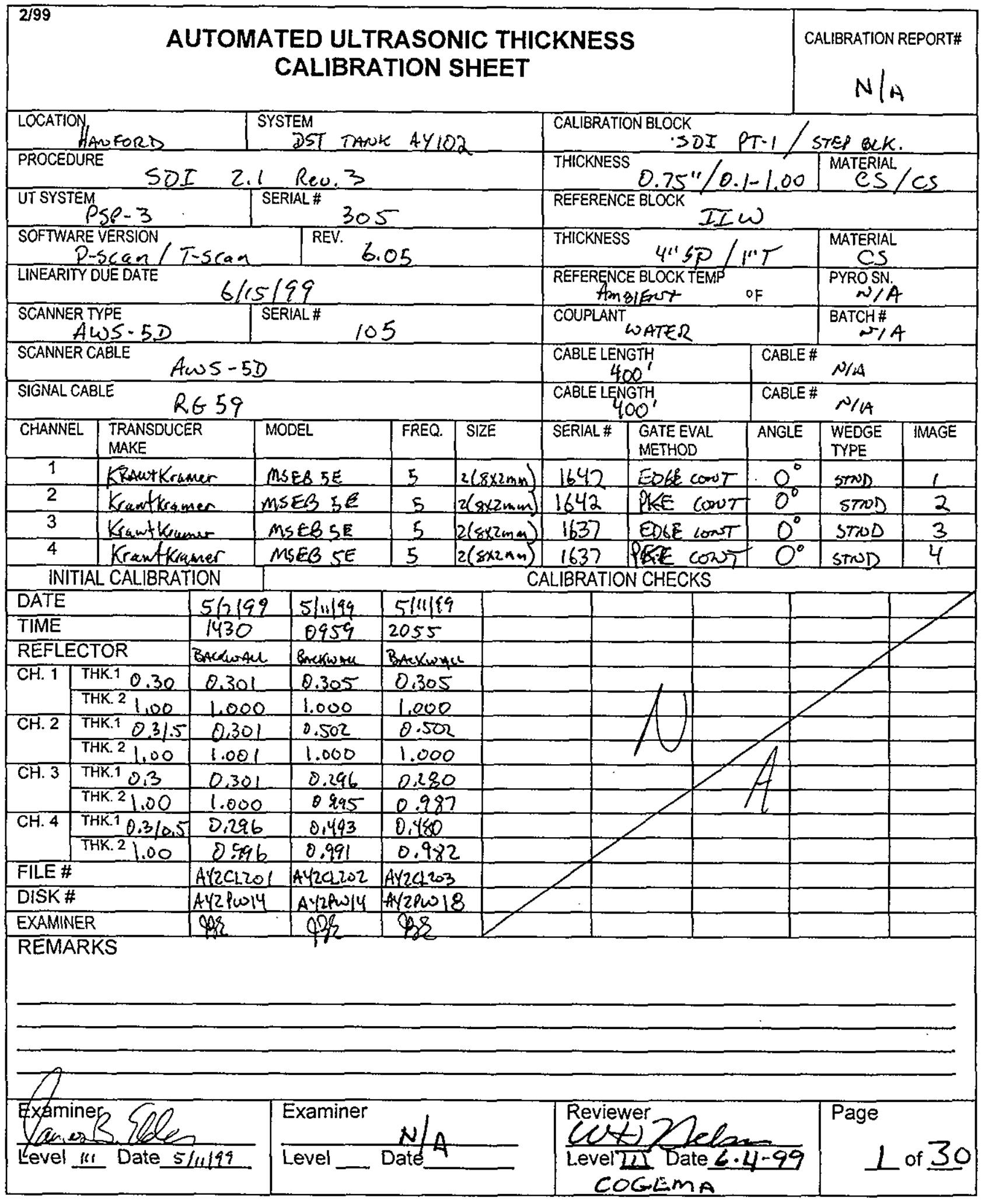




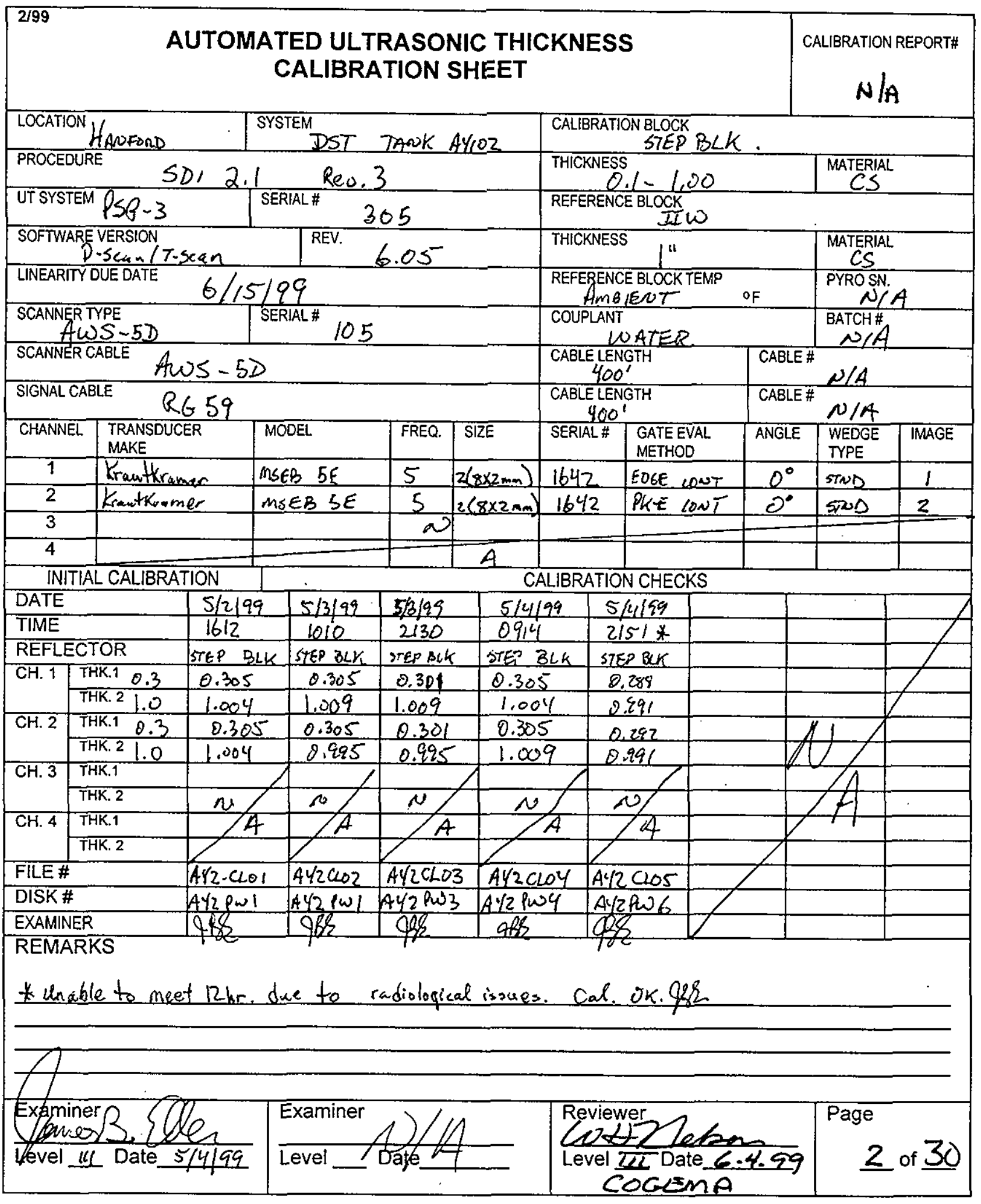




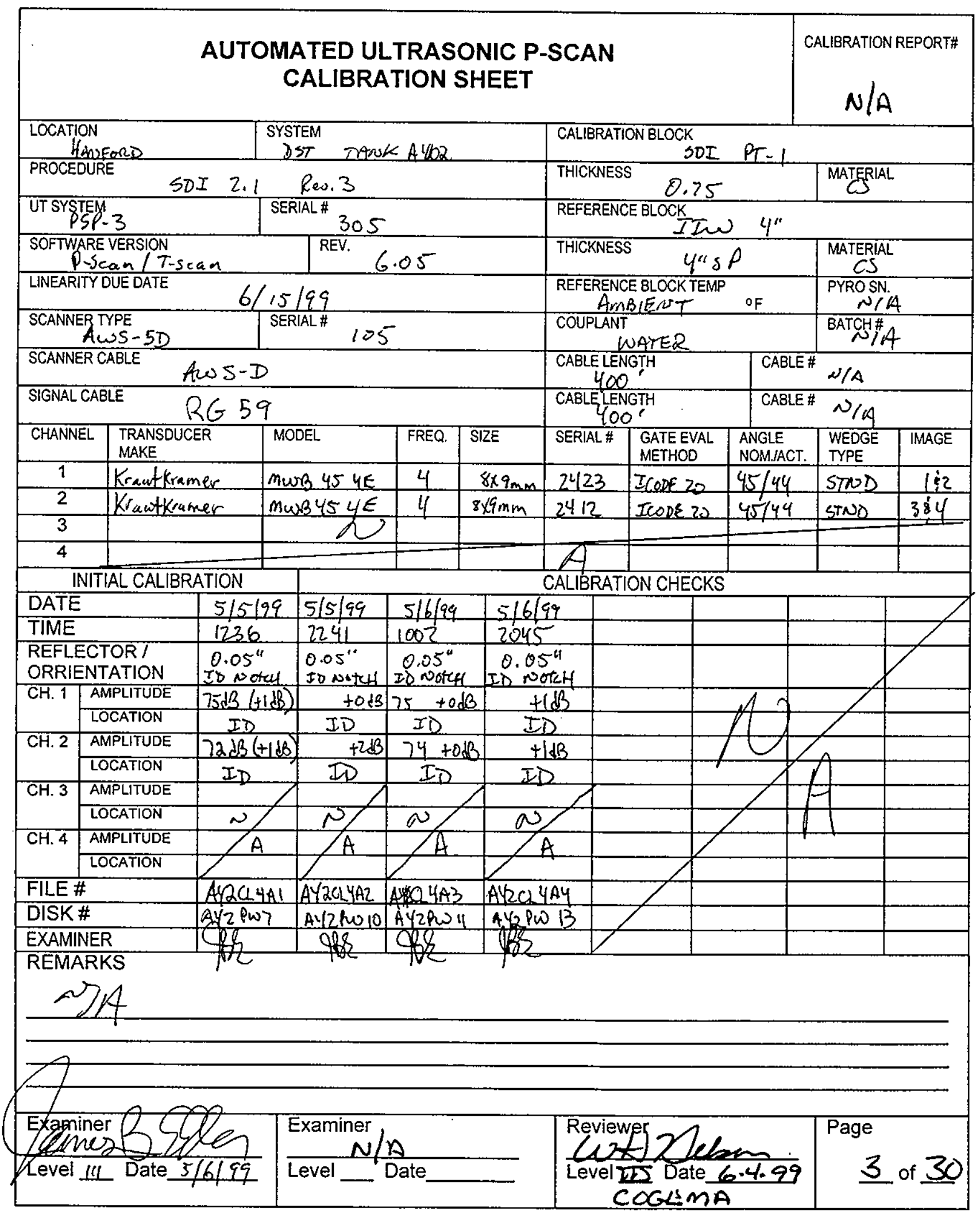




\section{AUTOMATED ULTRASONIC P-SCAN CALIBRATION SHEET}

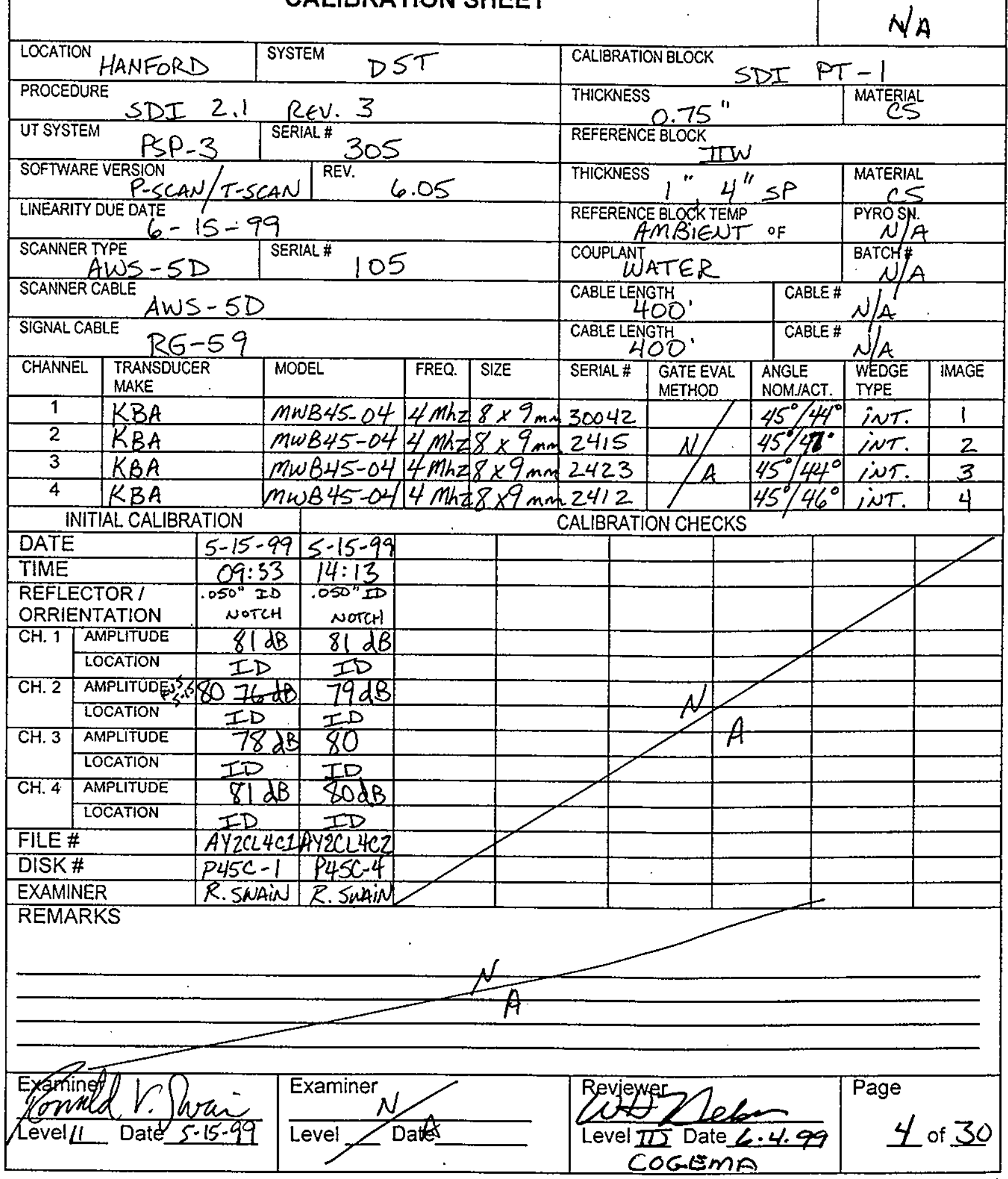




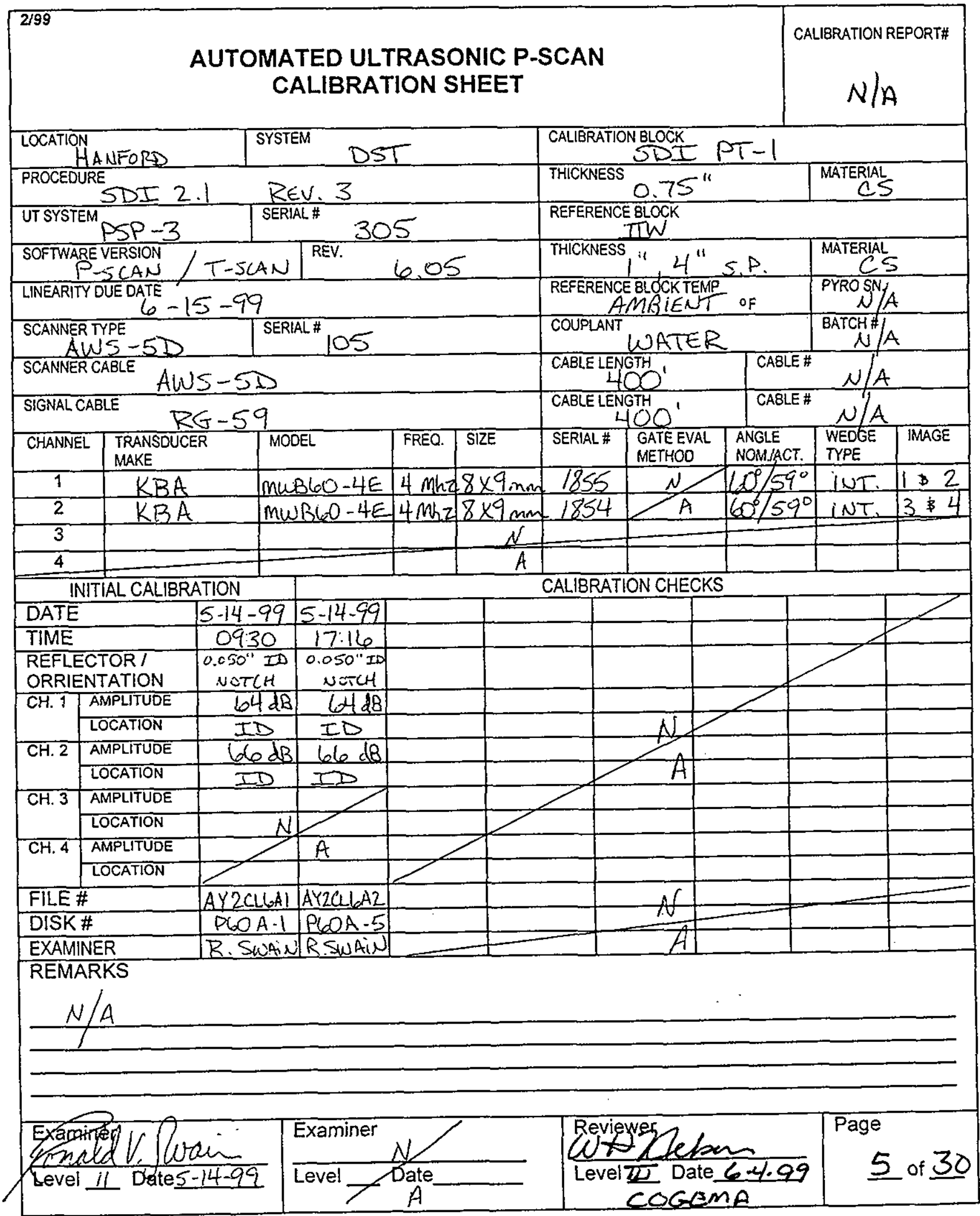




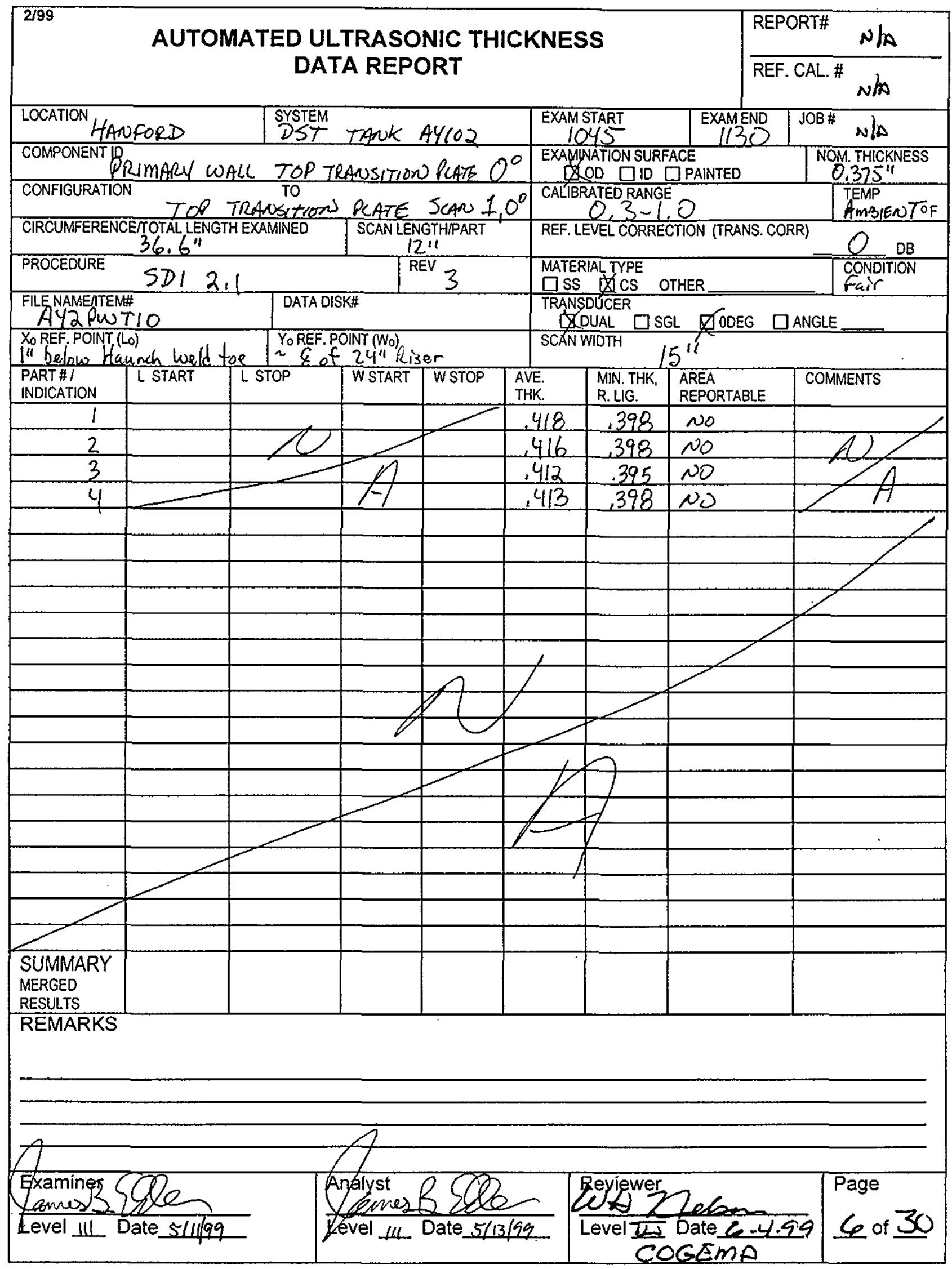




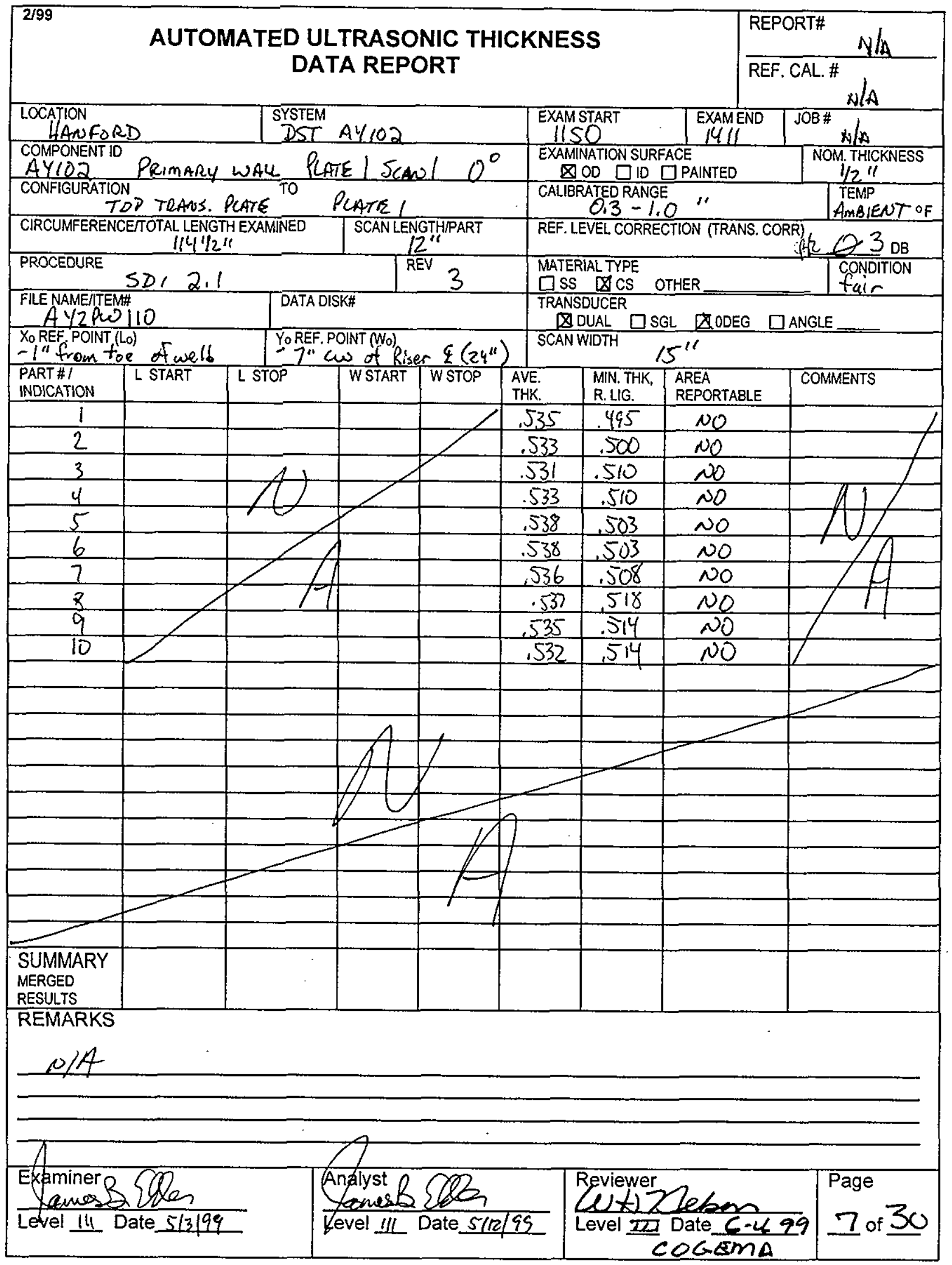




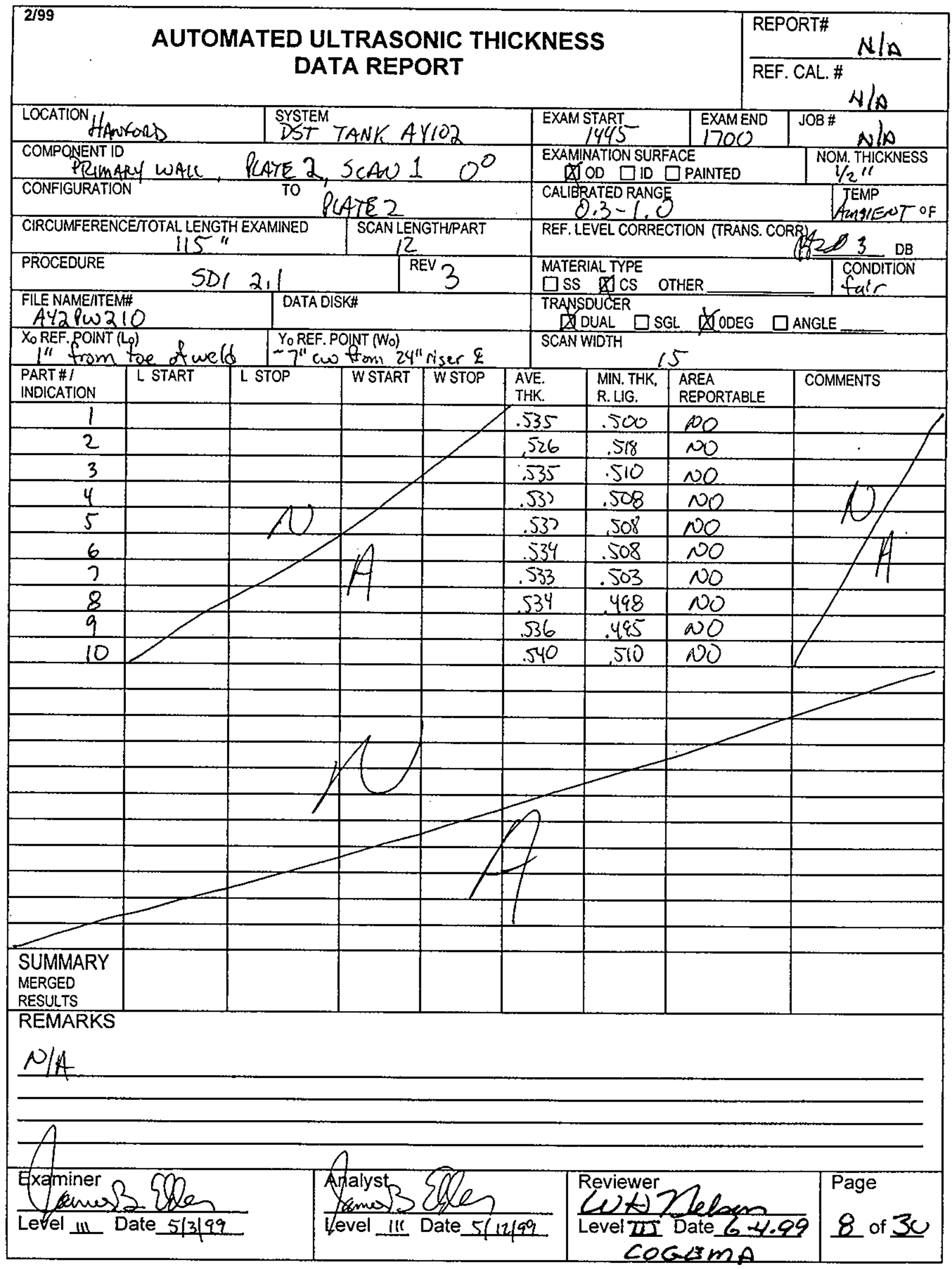




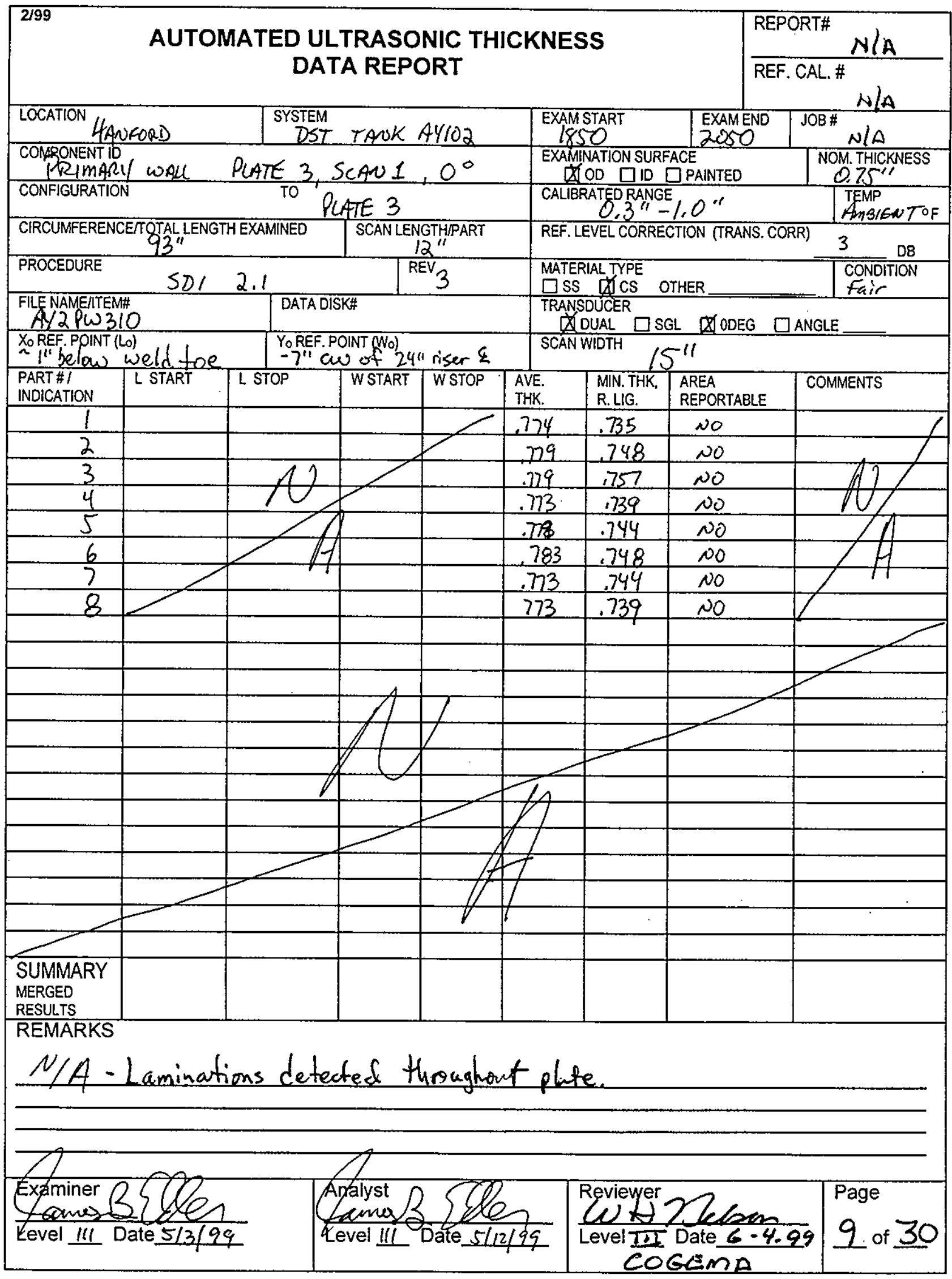


HNF - 4818

Rev. 0

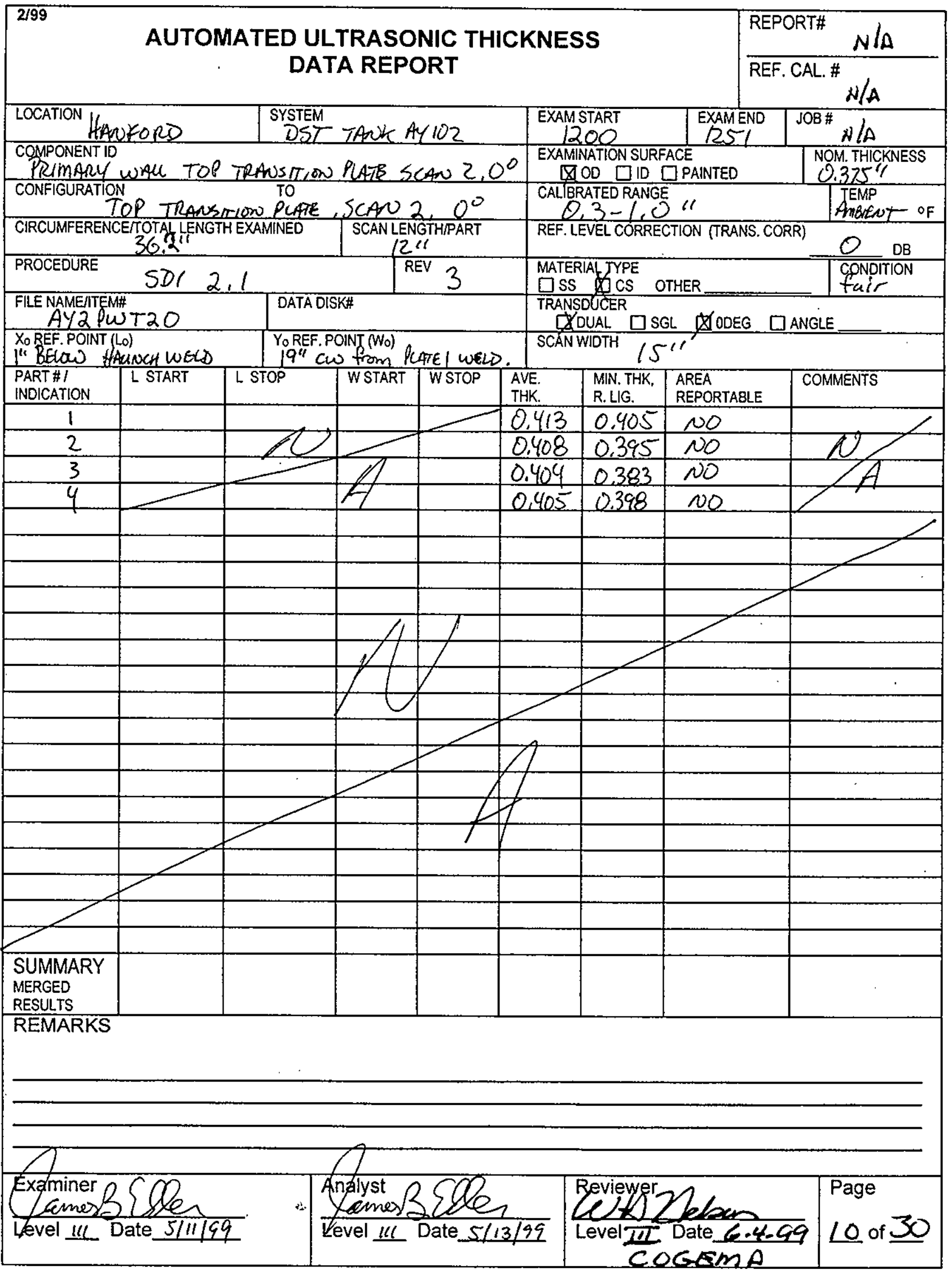




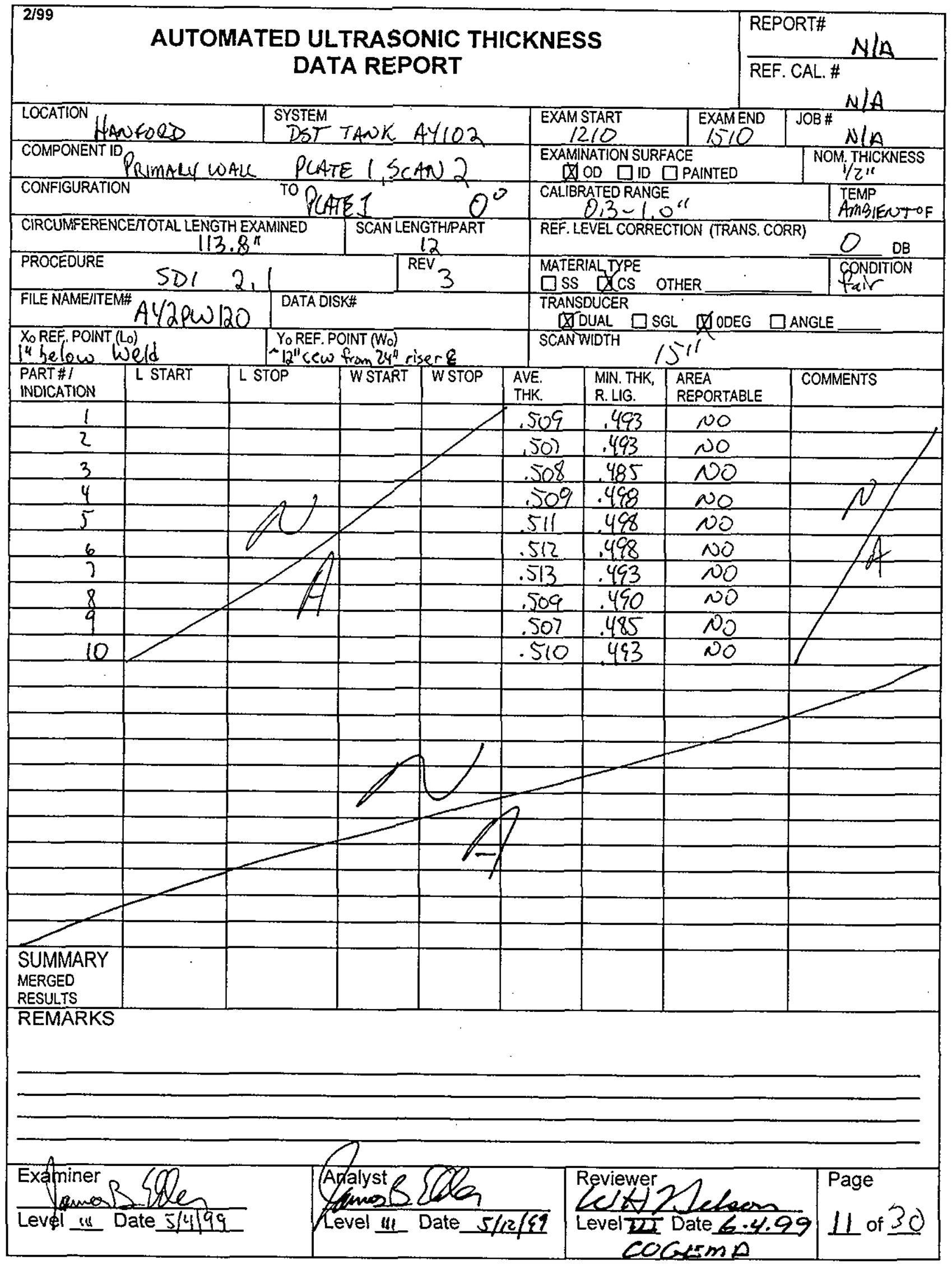




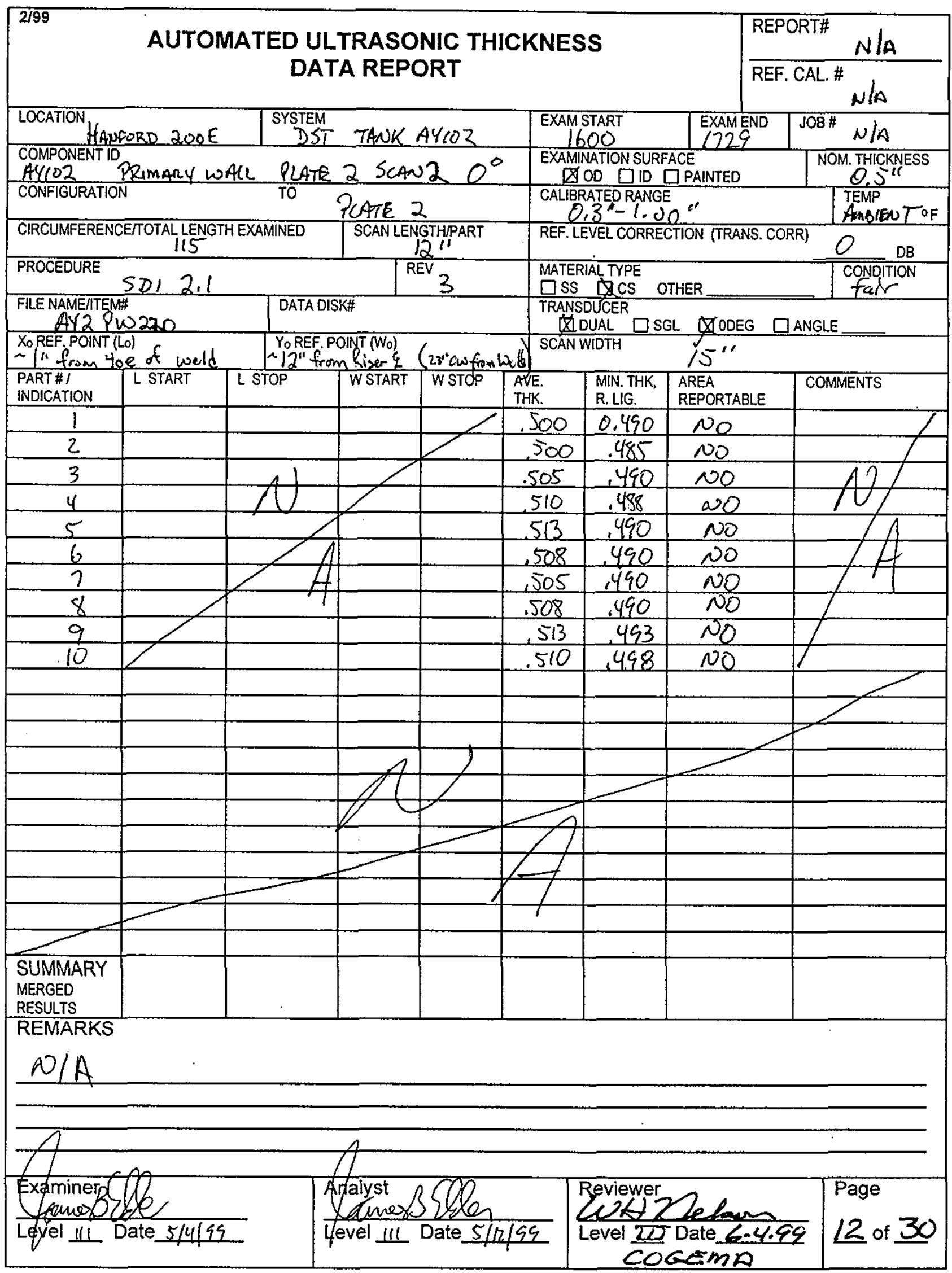




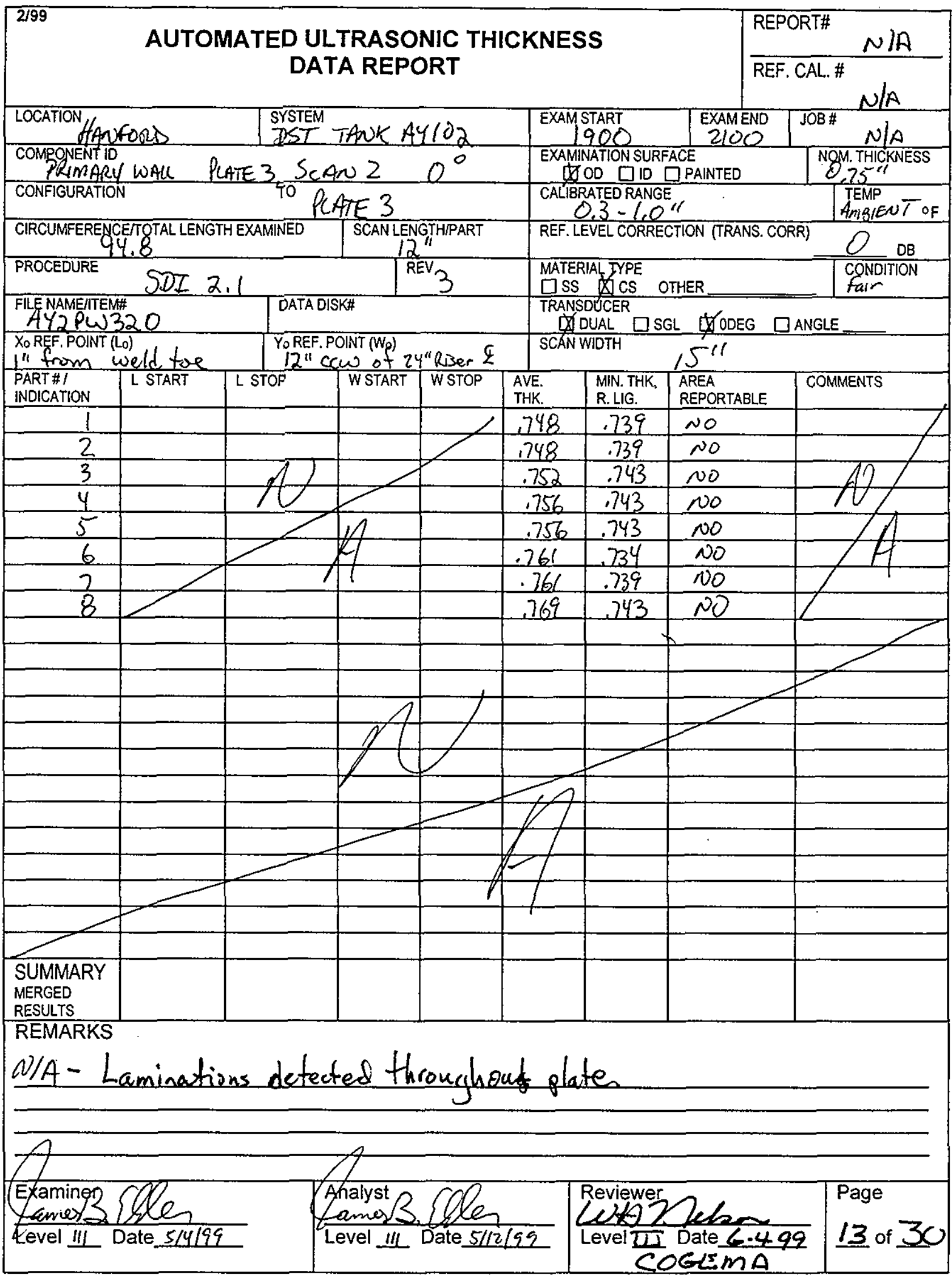




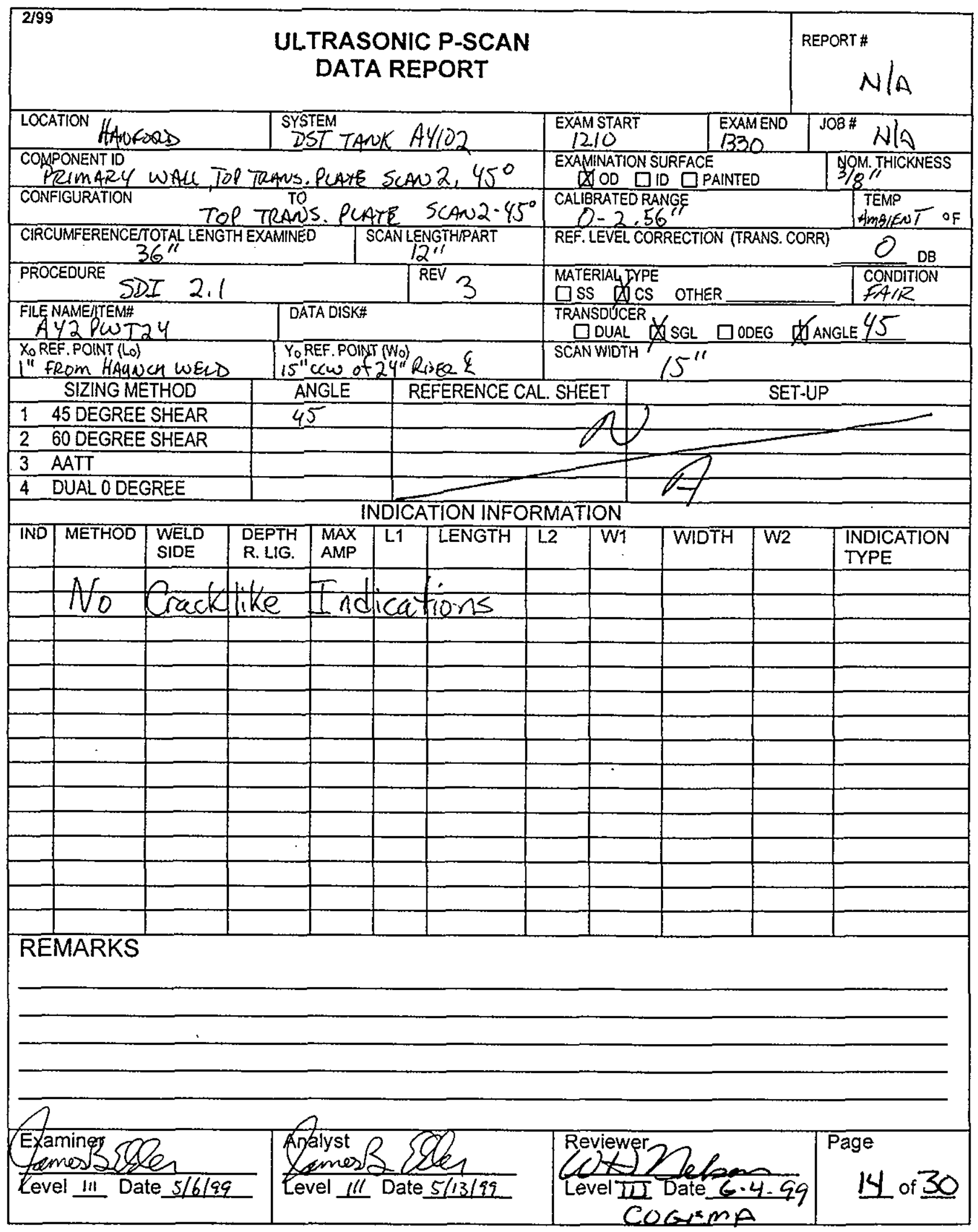




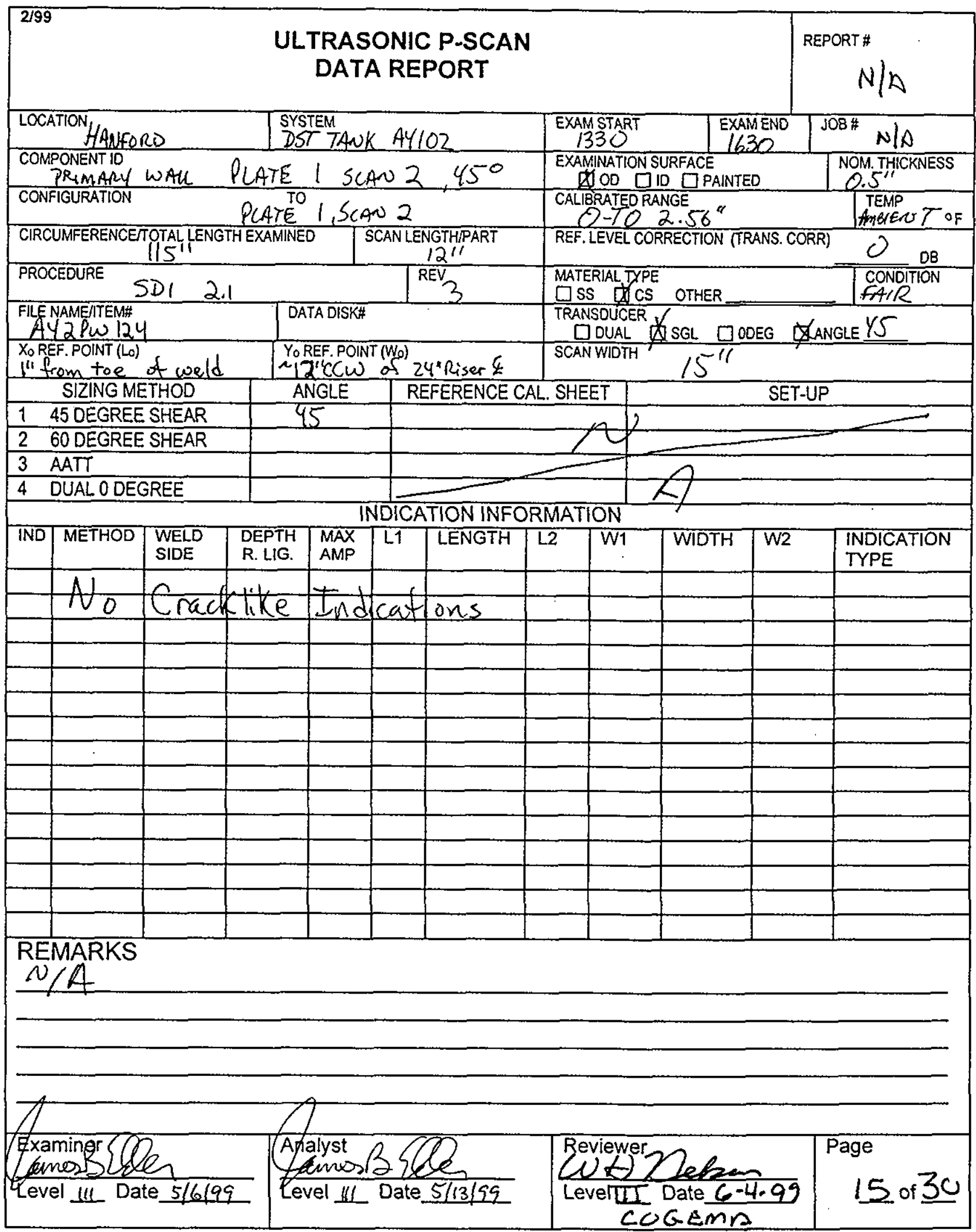




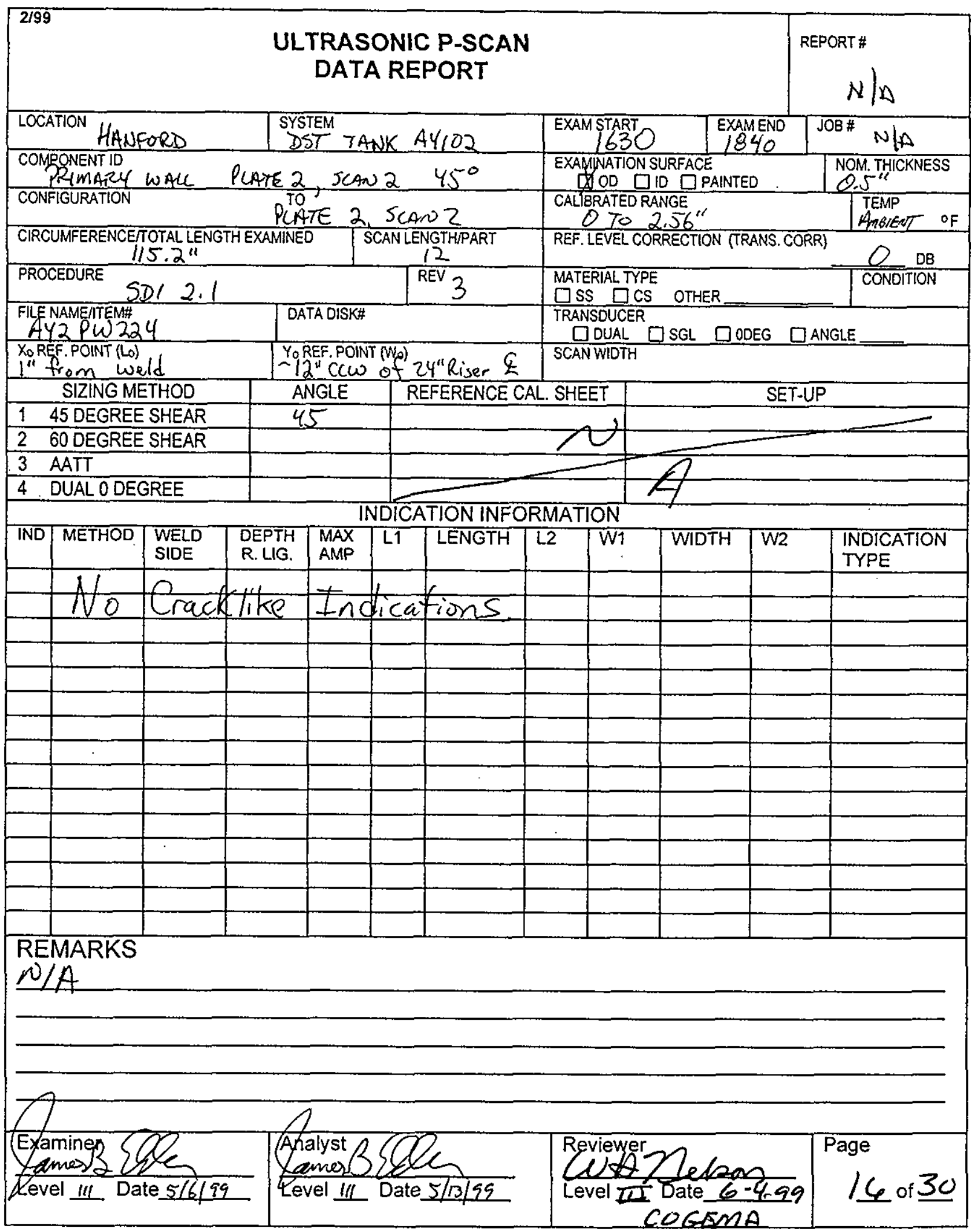




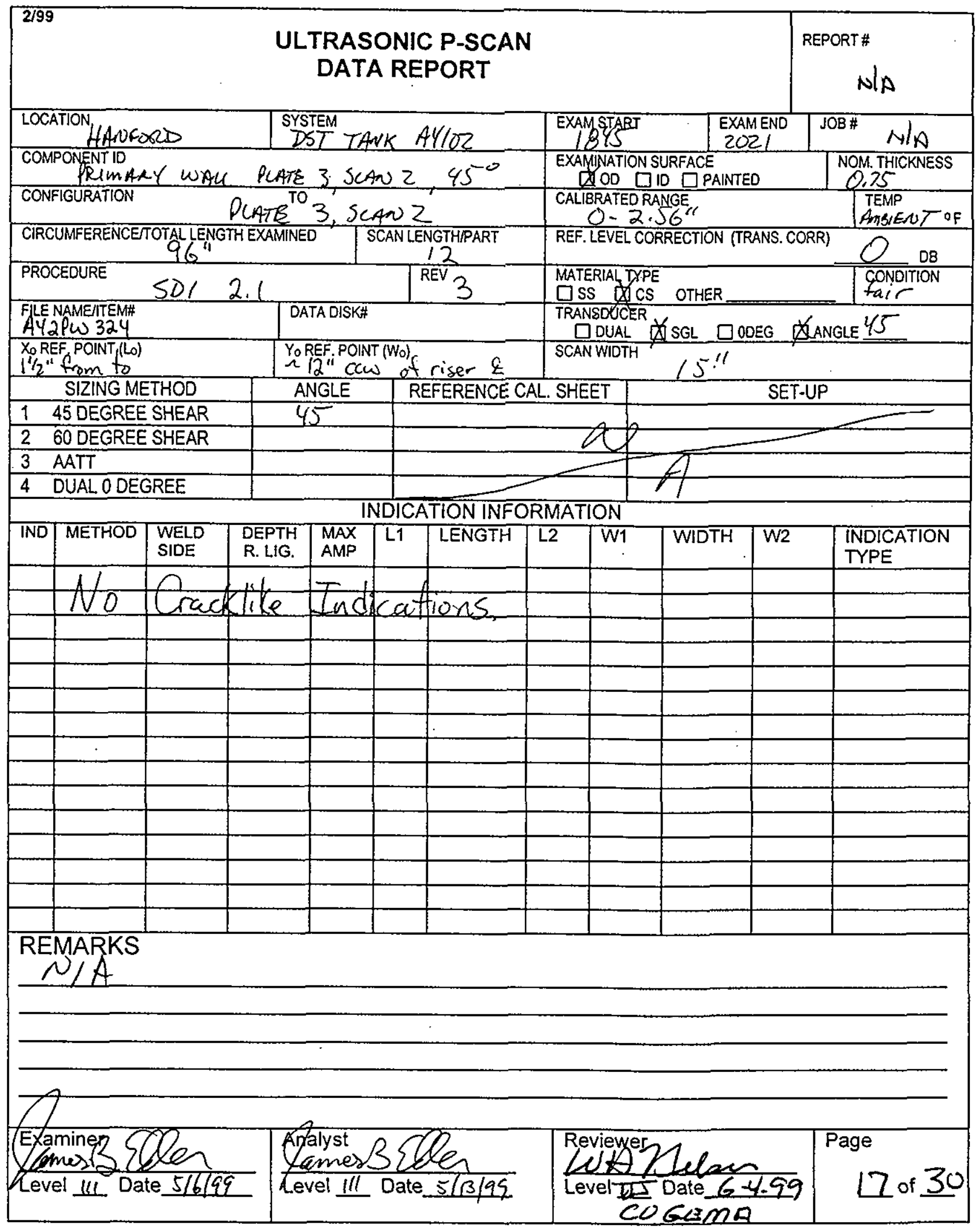




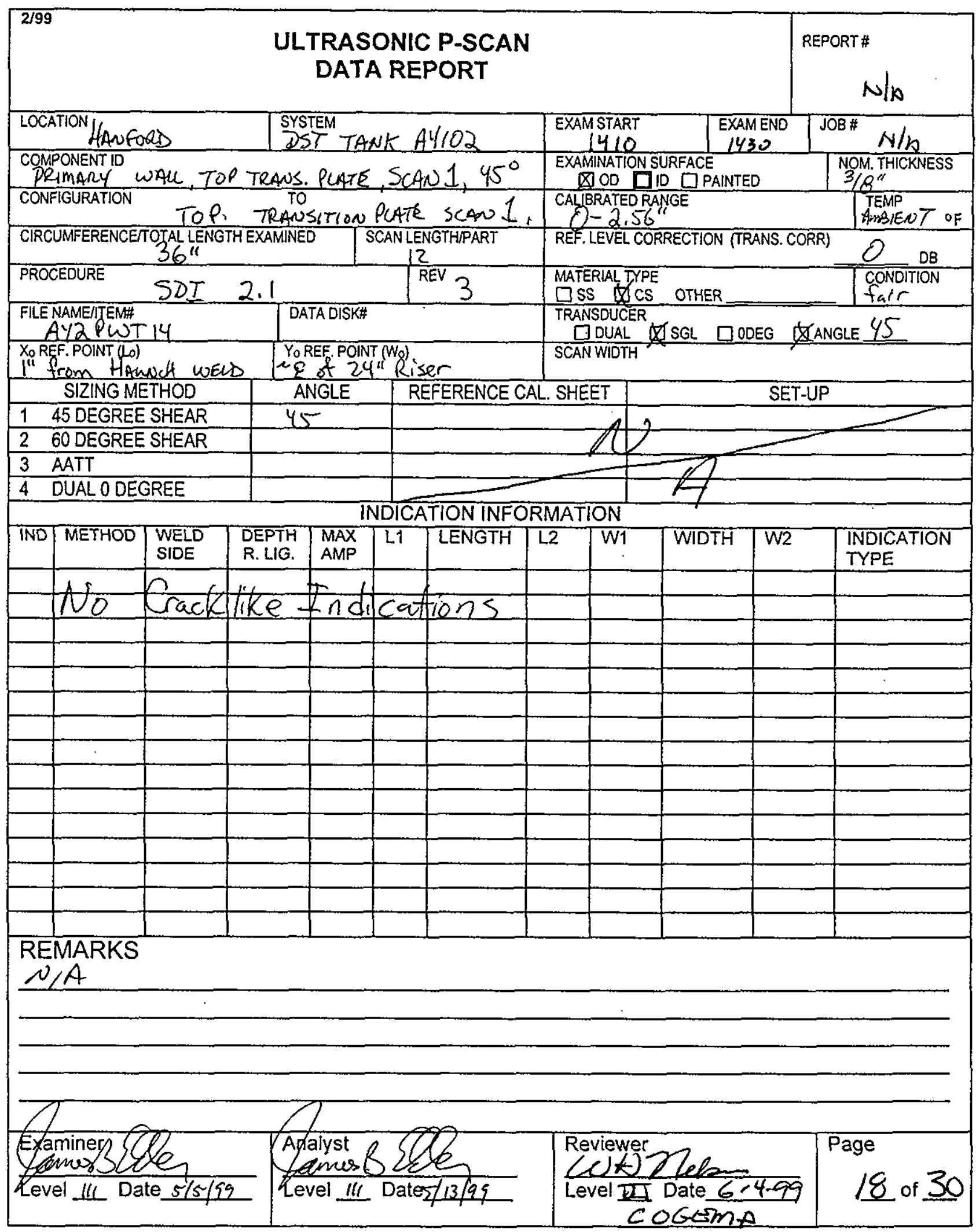




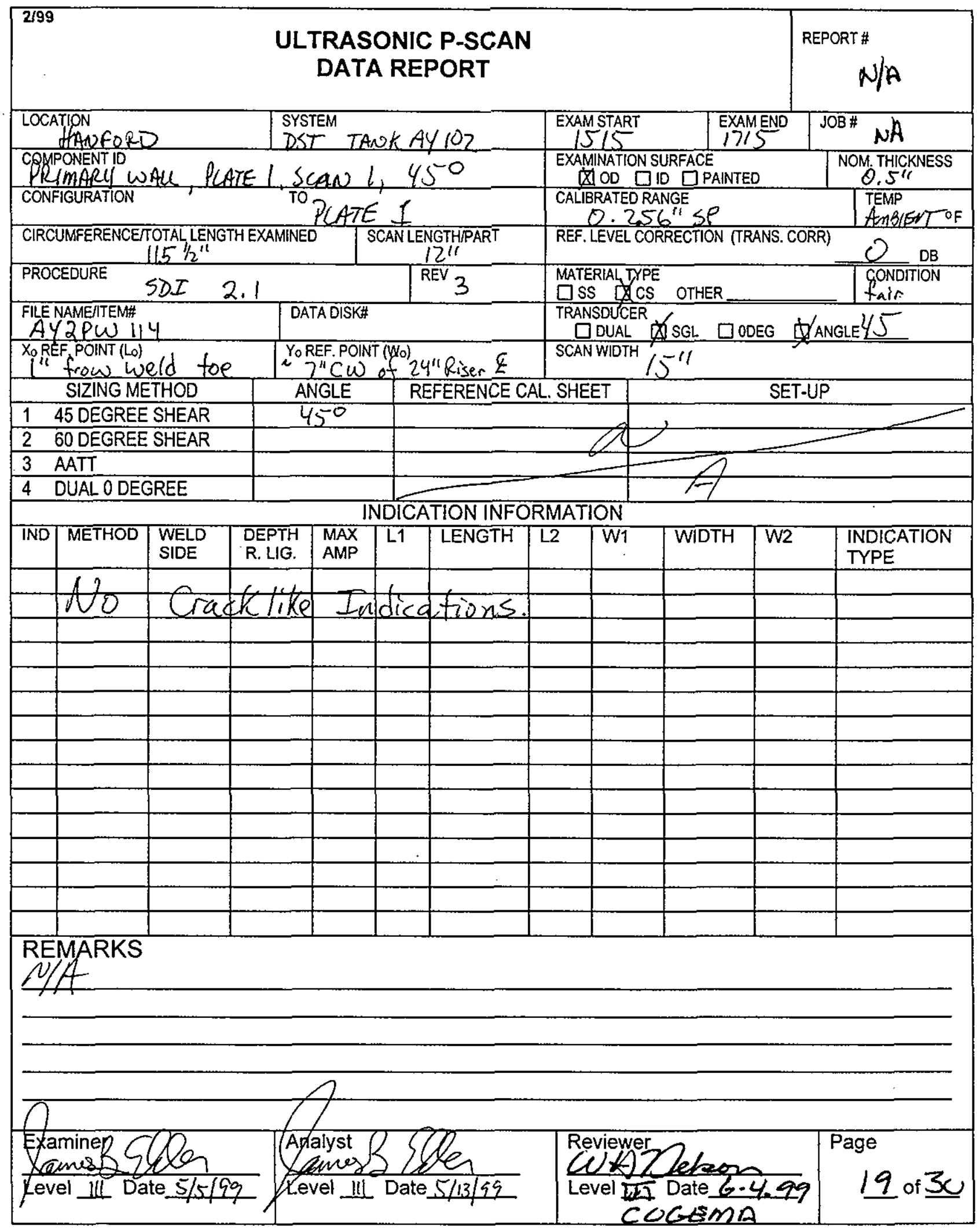




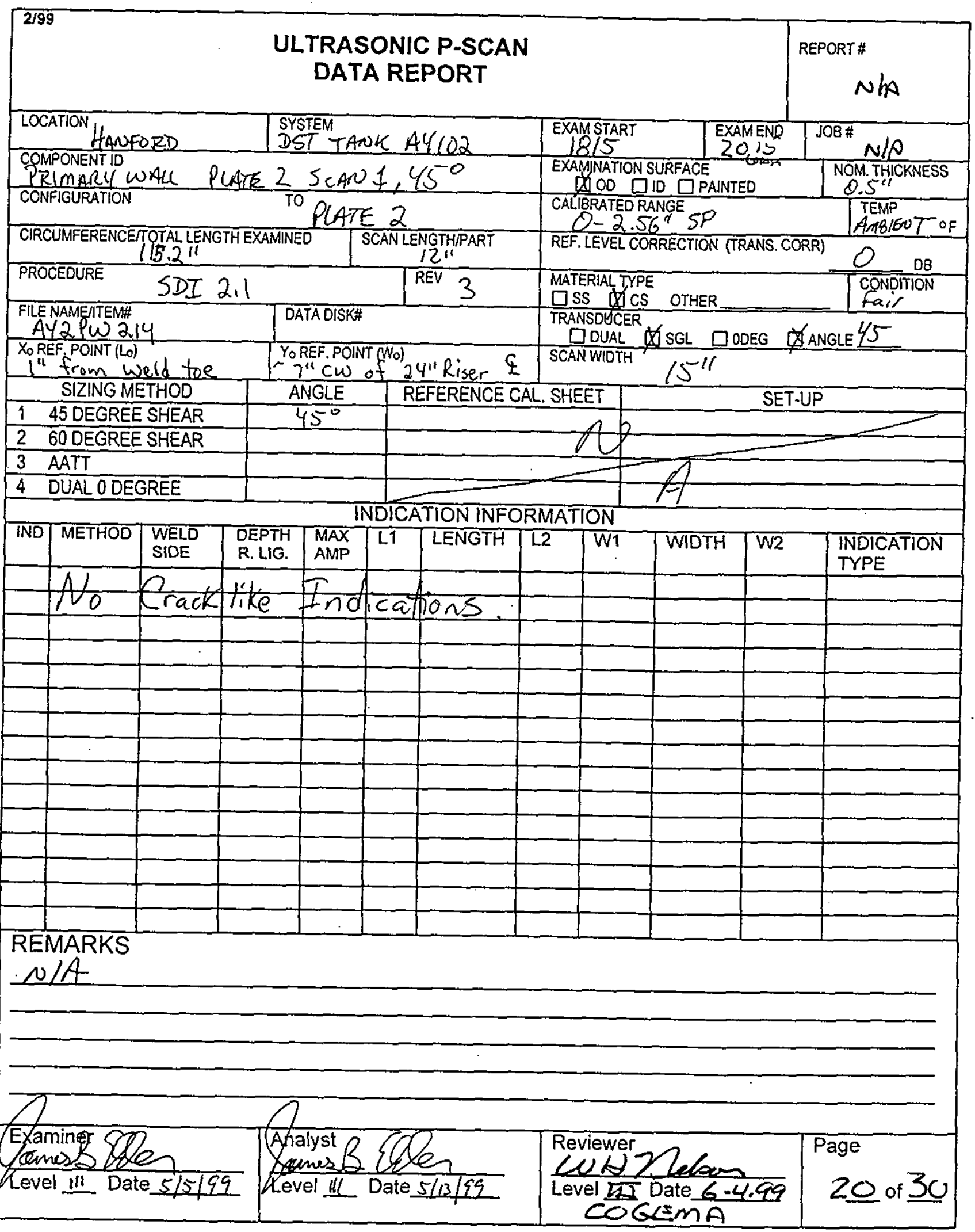




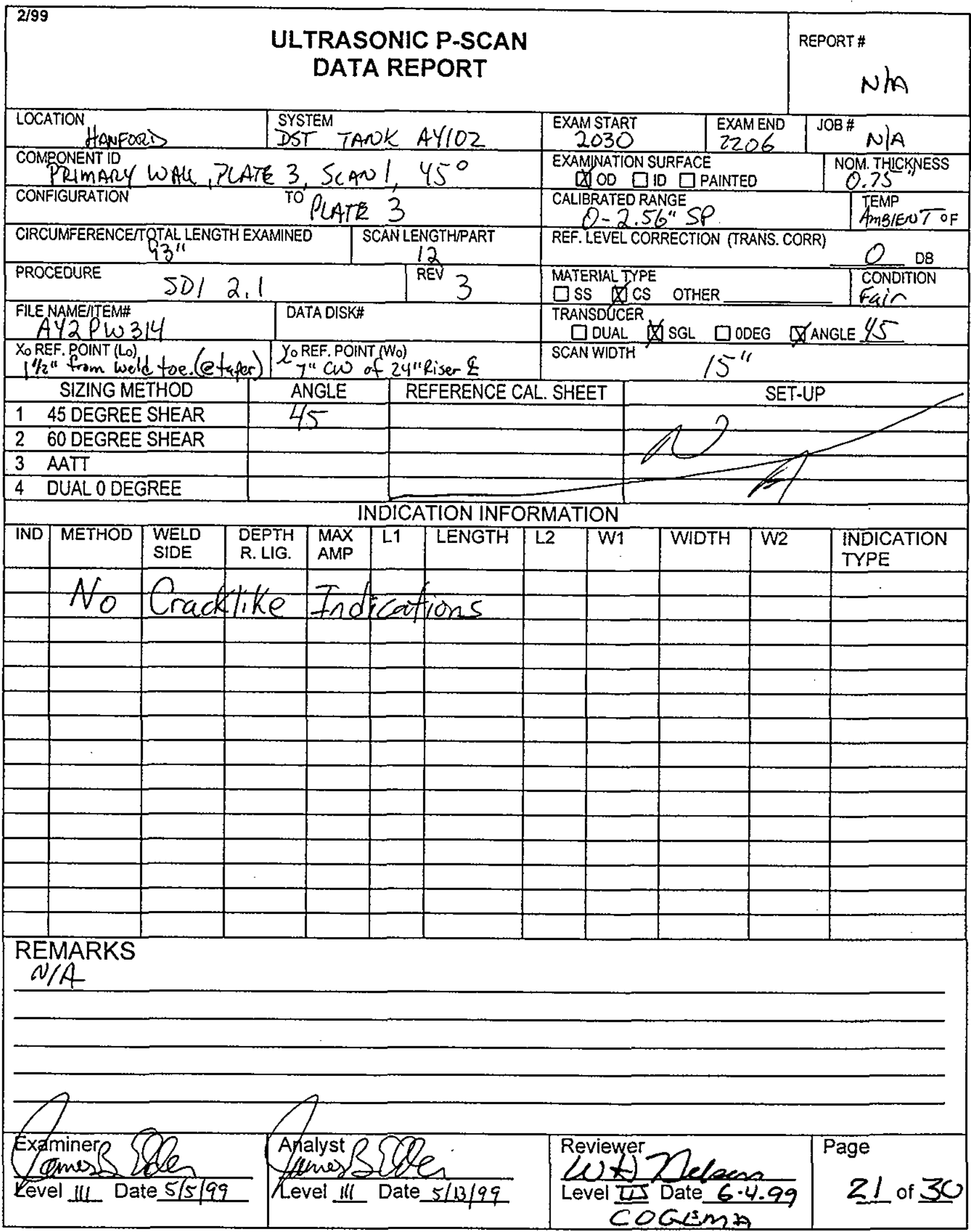




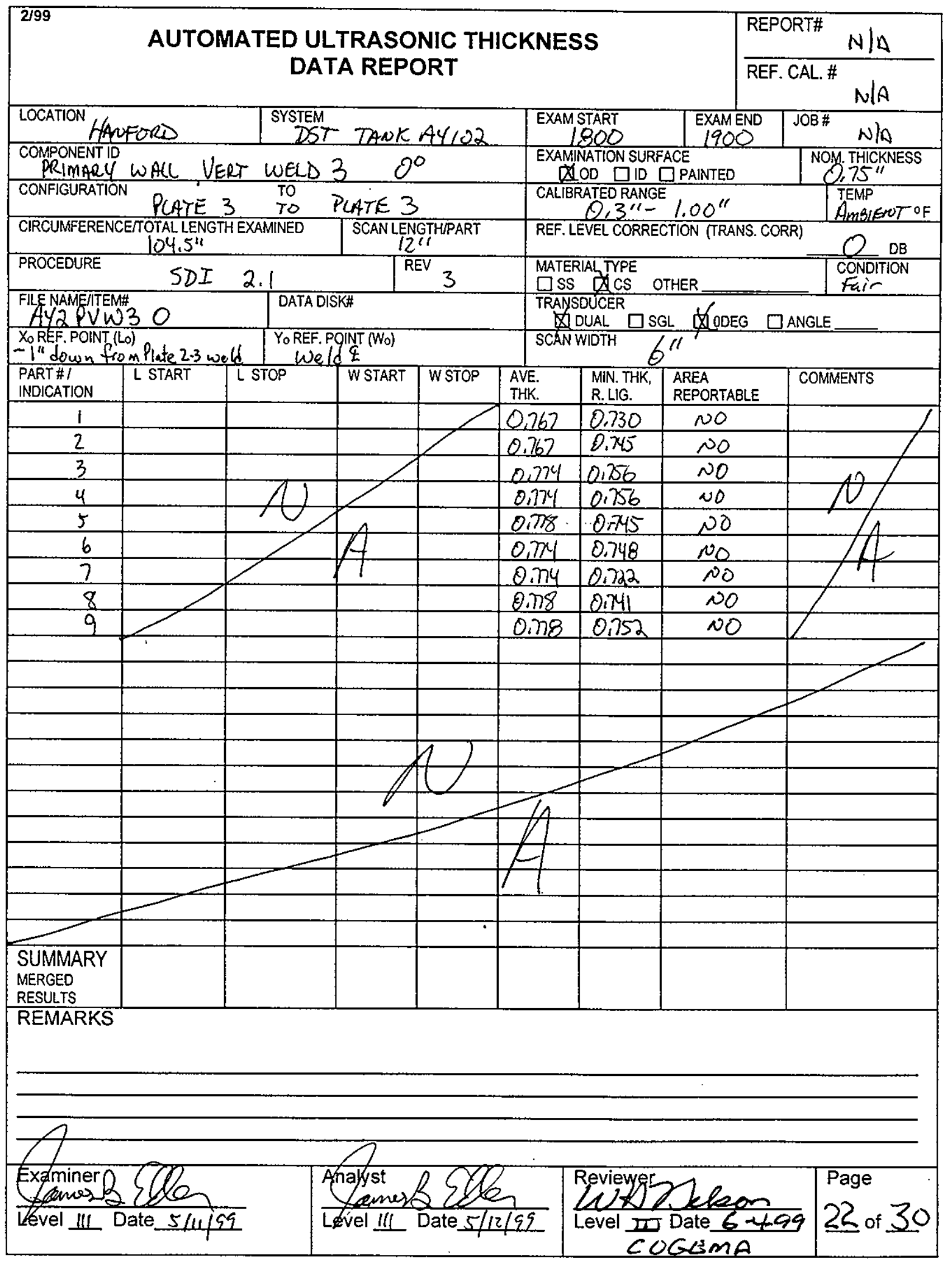




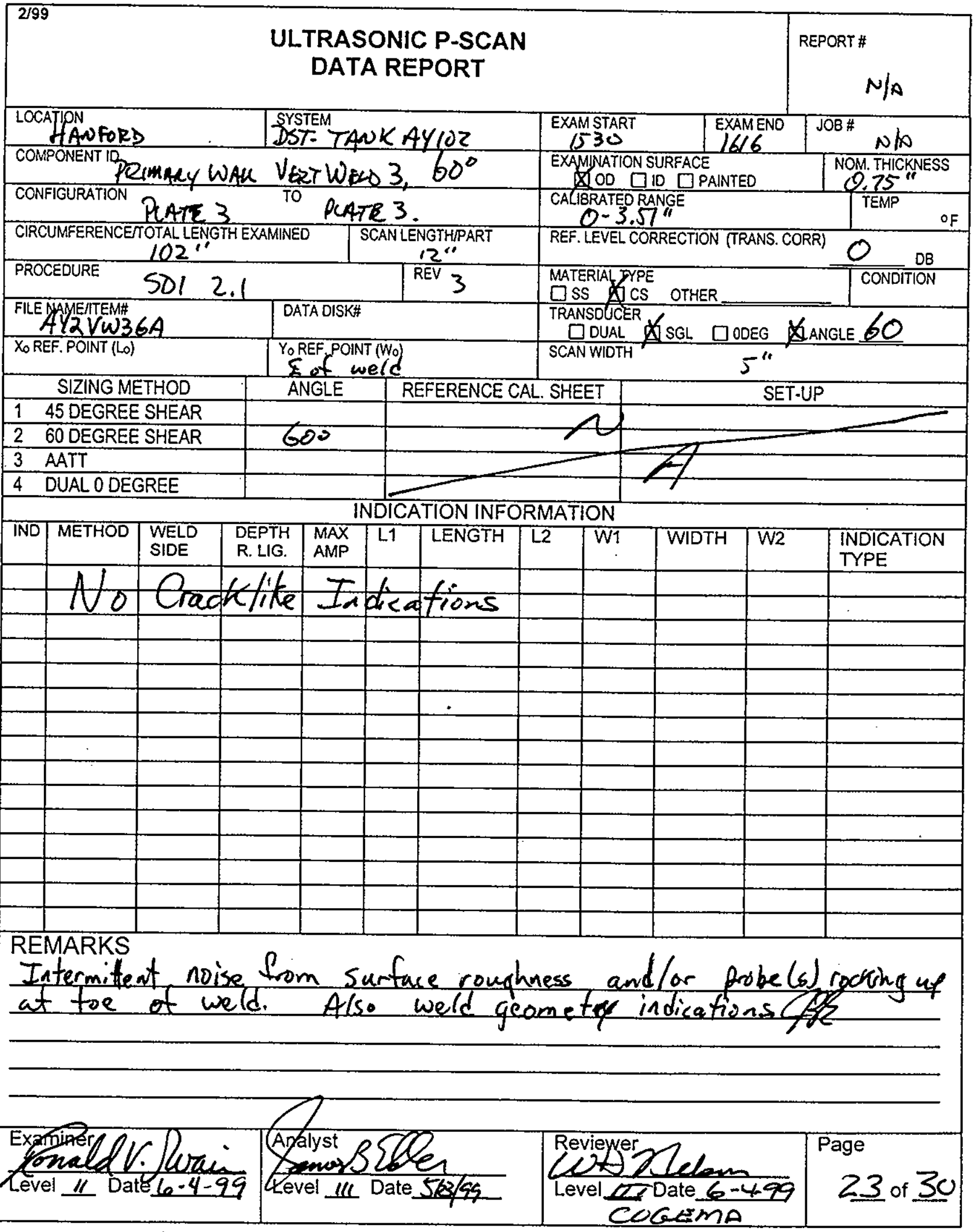

$$
110105
$$




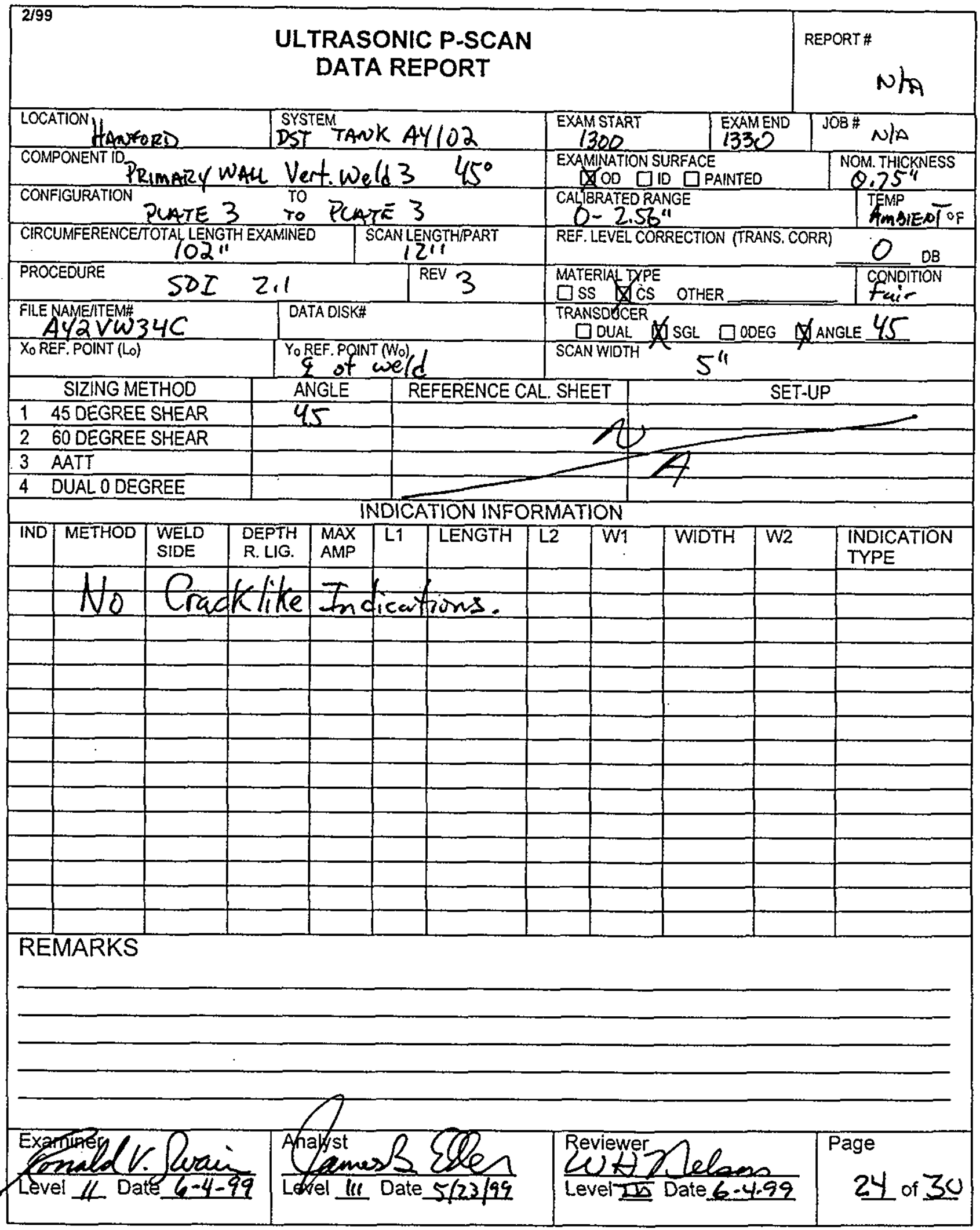

$$
519.56
$$




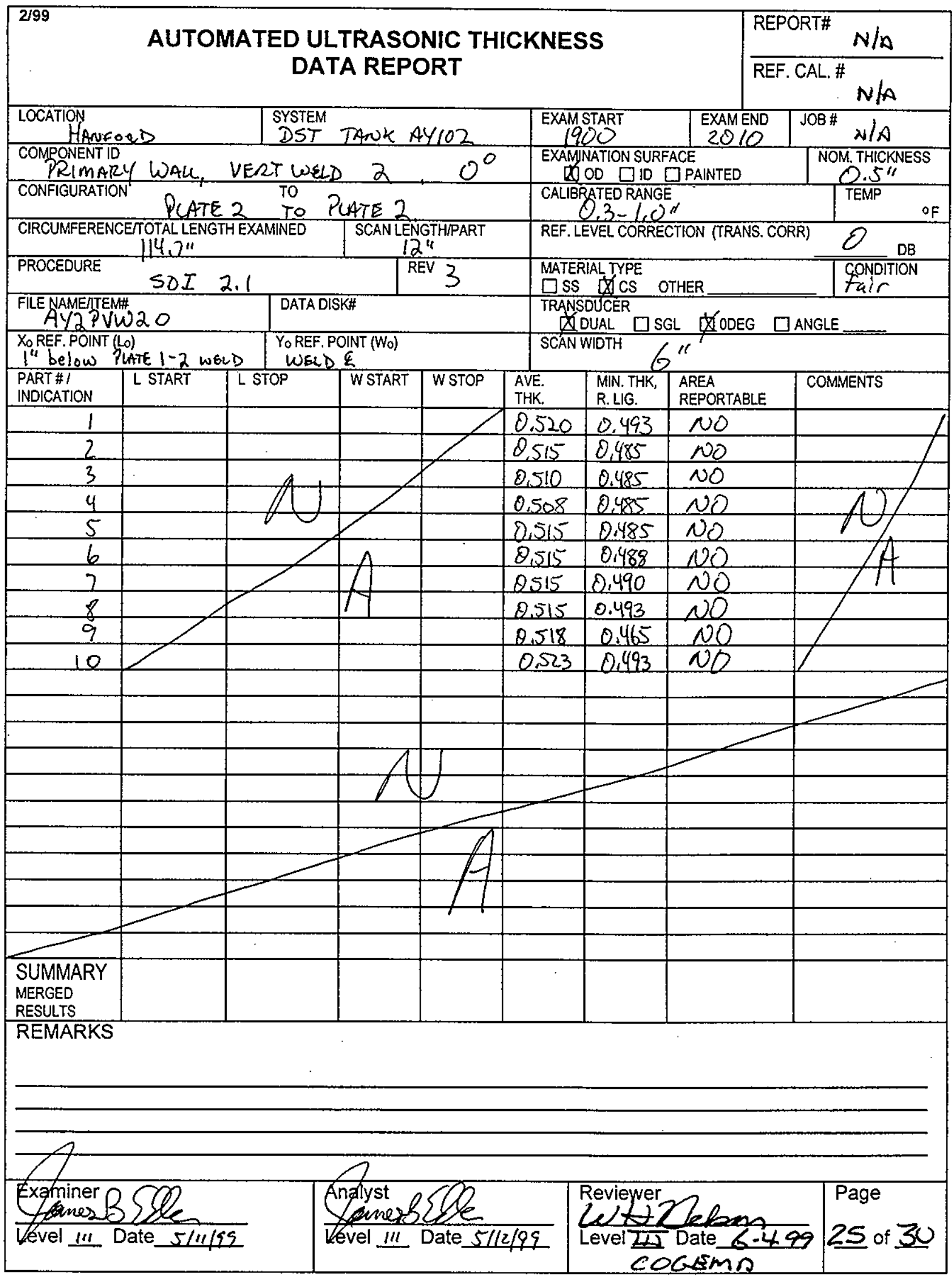




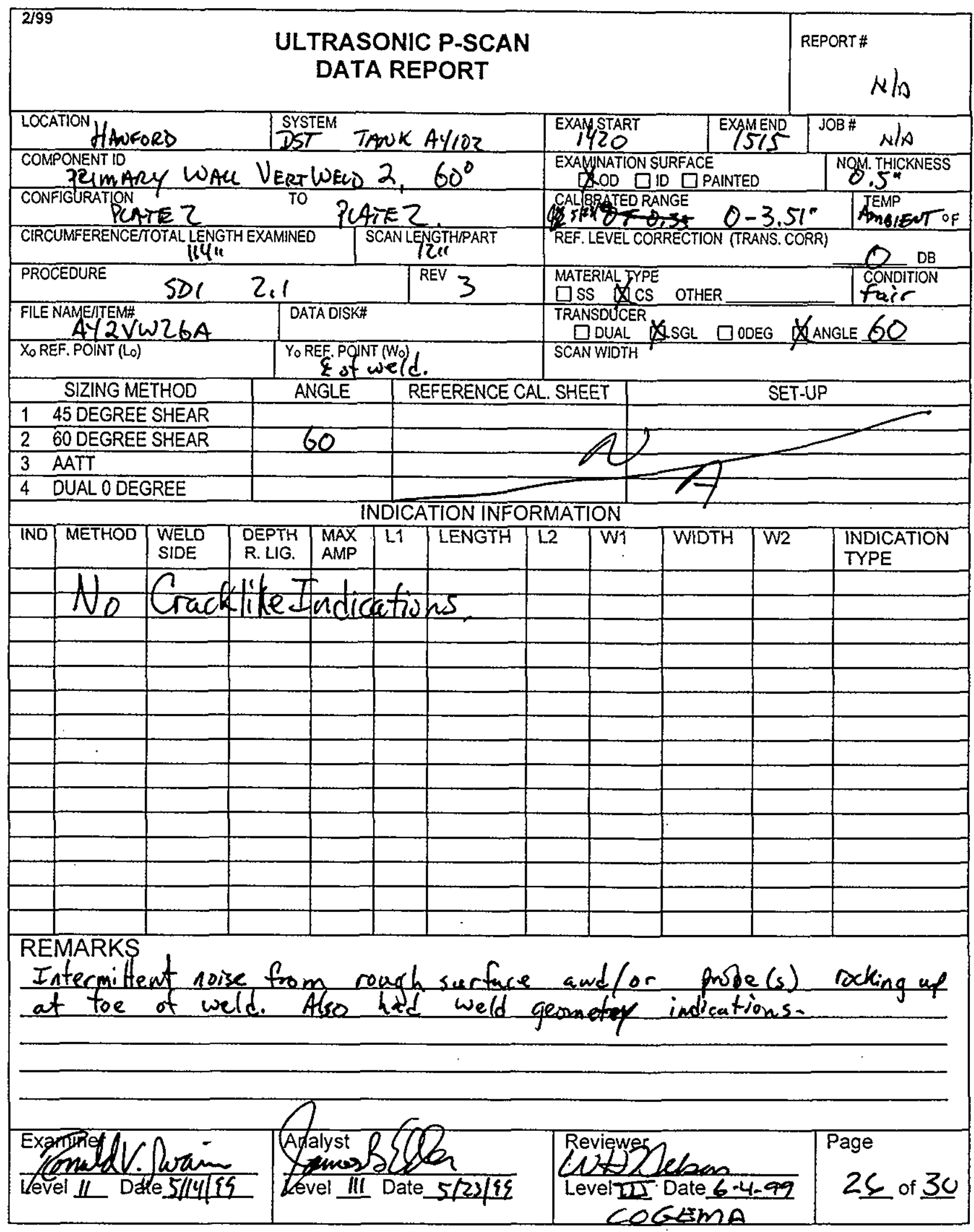




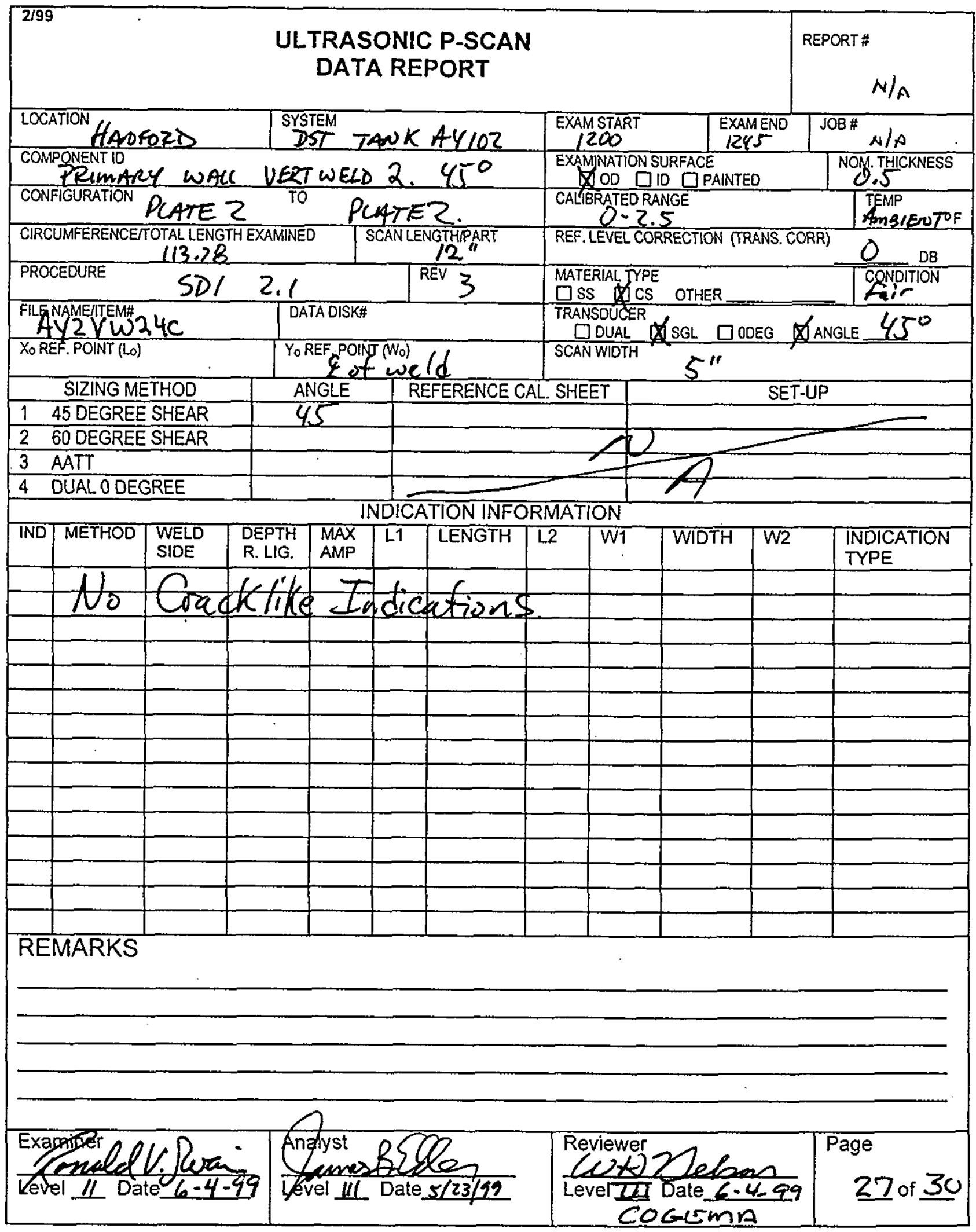




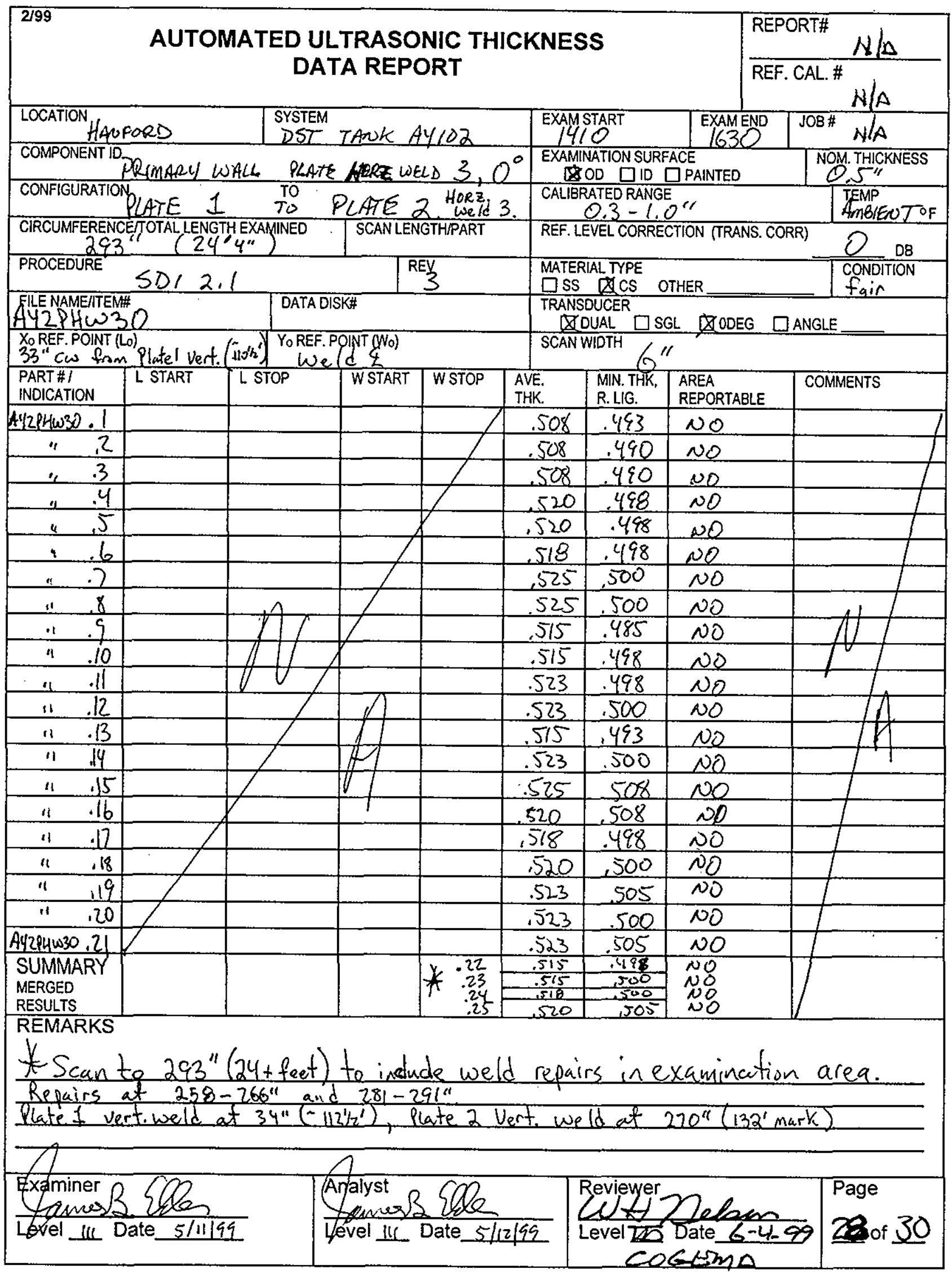




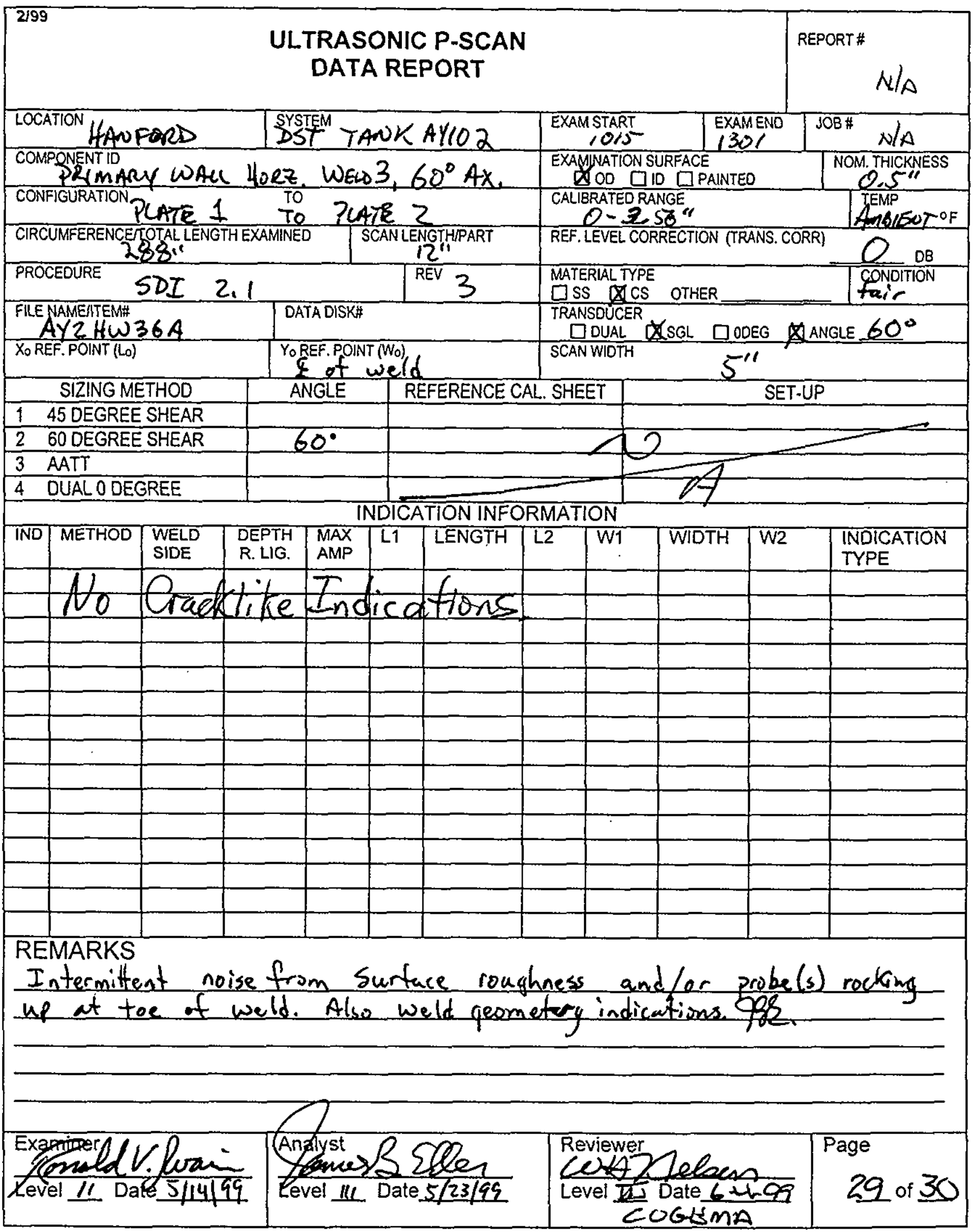




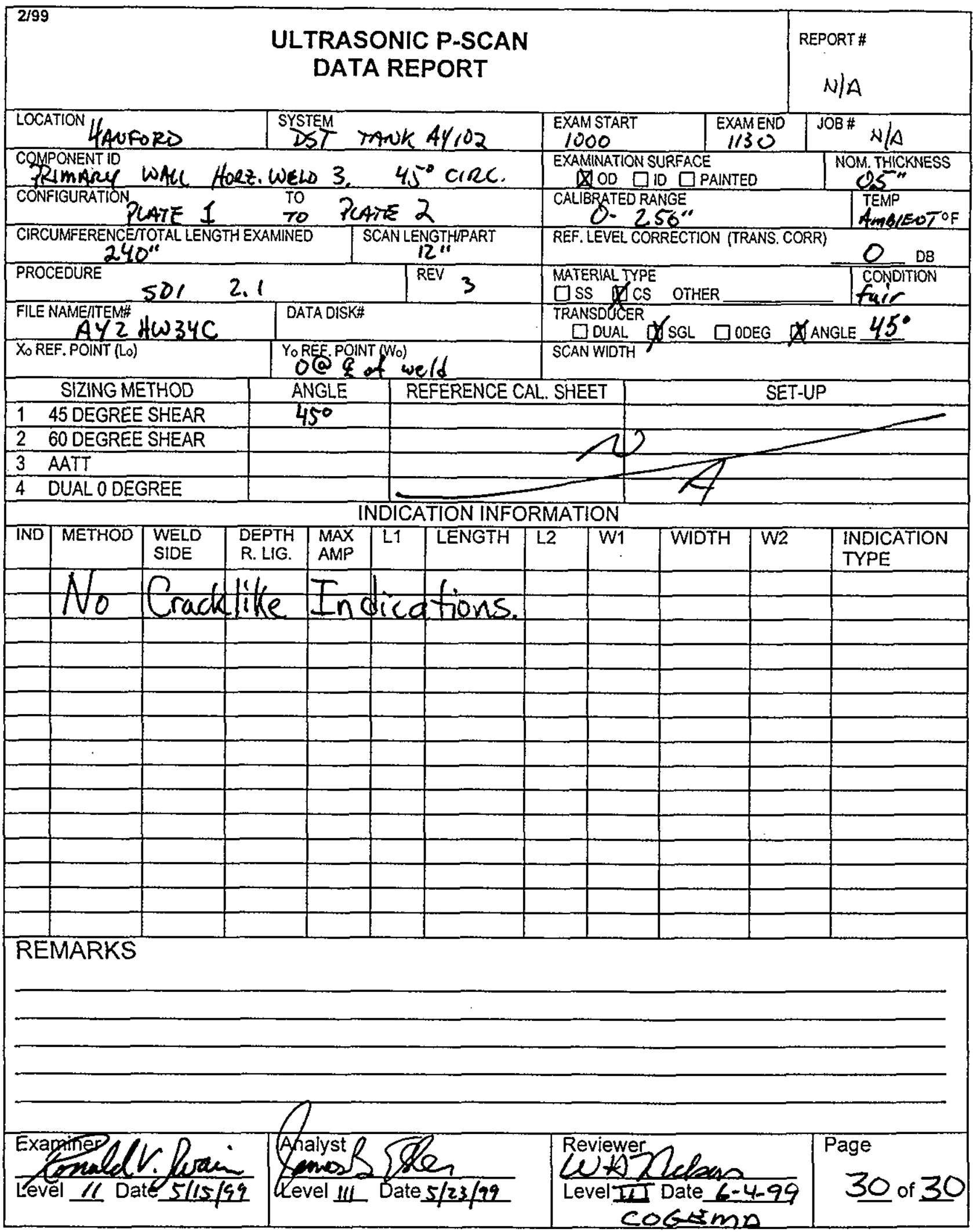




\section{DISTRIBUTION SHEET}

To

Distribution

Project Title/Work Order

Final Results of Double-Shell Tank 241-AY-102 Ultrasonic Inspection
From
Tank Systems Integrity Engr'g

\section{Name}

R. P. Anantatmula

D. L. Becker

B. G. Erlandson

E. A. Fredenburg

H. R. Hopkins, III

C. E. Jensen

L. J. Julyk

P. C. Miller

E. A. Nelson

M. A. Payne

D. C. Pfluger

R. S. Popielarczyk

R. W. Powell

W. J. Powell

D. S. Rewinkel

S. H. Rifaey

W. E. Ross

D. B. Smet

T. B. Veneziano

K. A. White

D. G. Baide

M. L. Dexter

E. E. Mayer

A. F. Pardini

G. J. Posakony
Page 1 of 1

Date $7 / 21 / 99$

EDT No. 623398

ECN No.

\begin{tabular}{|c|c|c|c|c|}
\hline MSIN & $\begin{array}{c}\text { Text } \\
\text { With All } \\
\text { Attach. }\end{array}$ & Text Only & $\begin{array}{c}\text { Attach.I } \\
\text { Appendix } \\
\text { Only }\end{array}$ & $\begin{array}{c}\text { EDT/ECN } \\
\text { Only }\end{array}$ \\
\hline$R 1-30$ & $x$ & & & \\
\hline R3-73 & $x$ & & & \\
\hline R1-51 & & & & $x$ \\
\hline $\mathrm{R} 1-56$ & $\mathrm{x}$ & & & \\
\hline$R 2-58$ & $\mathrm{x}$ & & & \\
\hline$R I-56$ & $x$ & & & \\
\hline$R 1-56$ & $\mathrm{x}$ & & & \\
\hline R1-51 & $\mathrm{x}$ & & & \\
\hline$L 6-38$ & $\mathrm{x}$ & & & \\
\hline$R 2-58$ & & & & $x$ \\
\hline$R 1-56$ & $x$ & & & \\
\hline$R 2-58$ & & & & $\mathrm{x}$ \\
\hline R3-75 & $x$ & & & \\
\hline G1-54 & $x$ & & & \\
\hline $57-40$ & $\mathrm{x}$ & & & \\
\hline $\mathrm{R} 1-56$ & $x$ & & & \\
\hline $\mathrm{R} 2-50$ & $x$ & & & \\
\hline$R 1-56$ & $\mathrm{x}$ & & & \\
\hline $57-40$ & $\mathrm{x}$ & & & \\
\hline s5-13 & $x$ & & & \\
\hline s5-05 & $x$ & & & \\
\hline $\mathrm{R} 1-51$ & $x$ & & & \\
\hline$R 2-50$ & & & & $\mathrm{x}$ \\
\hline $\mathrm{K} 5-26$ & $\mathrm{x}$ & & & \\
\hline K5-26 & $x$ & & & \\
\hline & & & & \\
\hline & & & & \\
\hline & & & & \\
\hline & & & & \\
\hline & & & & \\
\hline & & & & \\
\hline & & & & \\
\hline
\end{tabular}

